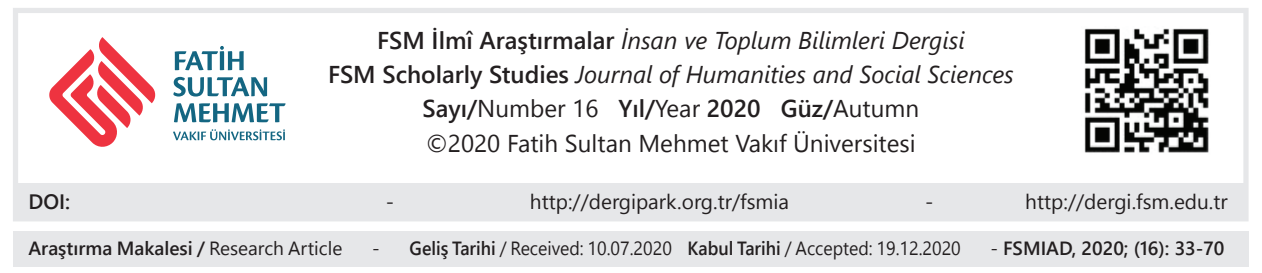

\title{
Çin-Japonya Çatışması ve Türkiye'nin Uzakdoğu Gelişmelerine Bakışı (1929-1939)
}

Melih Duman*

\section{$\ddot{O} z$}

Çalışma, iki dünya savaşı arası olarak nitelendirilen dönemde Uzakdoğu'da ağırlıklı olarak Japonya'nın meydana getirdiği gelişmeler karşısında, Türk dış politikasını ele alarak Türkiye'nin olayları nasıl değerlendirdiğini analiz etmektedir. 1929 yılında ÇinSSCB meselesi olarak başlayan, fakat daha sonrasında Japon-Çin meselesi haline gelen süreç, II. Dünya Savaşına kadar olan dönemde, Türkiye açısından ele alınmaktadır. Türkiye'nin, Japonya'nın Mançurya'yı işgal etmesi sonrasında gelişmeleri dünya siyaseti ve uluslararası hukuk açısından nasıl ve hangi gerekçelerle takip ettiği, Türkiye'nin Japonya ve Çin'le olan ikili ilişkilerine bu sürecin sirayet edip etmediği cevap aranan sorular arasındadır. Bu eksende dünyanın hızla yeni bir savaşa sürüklendiği bir dönemde, Japonya merkezli olarak Uzakdoğu'da meydana gelen çatışma ile Japonya'nın yayılmacılığı Türkiye açısından incelenmiştir. Çalışma, arşiv belgeleri, süreli yayınlar ve diğer kaynaklar doğrultusunda değerlendirilmiş̧ir.

Anahtar Kelimeler: Türkiye, Çin, Japonya, diplomasi, politika.

* $\quad$ Dr. Öğr. Üyesi, Aksaray Üniversitesi İletişim Fakültesi, Aksaray/Türkiye, melihduman@aksaray.edu.tr, orcid.org/0000-0001-6861-615X 


\title{
The Conflict between China and Japan and Turkey's Perspective on Developments in the Far East (1929-1939)
}

\begin{abstract}
The aim of the study is to address Turkish Foreign Policy against developments in the Far East and mainly in Japan during the inter-war period and analyze how Turkey assessed the events. The process, which started as Sino-Soviet Conflict in 1929 but later turned into Japan-China Issue, from Turkey's perspective during the period until the Second World War is examined.The research questions included how and with which reasons Turkey followed the developments after Japanese invasion of Manchuria in terms of world politics and international law and whether this process affected Turkey's bilateral relations with China and Japan. In this sense, it is analyzed that Japan-centered conflict in the Far East and Japan's expansionism in terms of Turkey during a period when the World was rapidly driven into a new war. The study was assessed using documentary literature survey in accordance with archive documents, periodicals, and other studies.
\end{abstract}

Keywords: Turkey, China, Japan, diplomacy, policy. 


\section{Giriş}

Dünya tarihinde XX. yüzyıl, diğer asırlara nazaran insanlık tarihinin en hızlı ve yoğun değişim yaşadığ 1 dönem olmuştur. Tarihsel süreci değiştiren iki önemli dünya savaşının XX. yüzyılda meydana gelmesi, keza her iki dünya savaşı sonrasında dünyanın yeniden şekillenmesi insanlık tarihi için önemli dönüm noktaları arasında olmuştur. İçerisinde yaşadığımız tarihsel süreç, II. Dünya Savaşı sonrasında oluşan yeni paradigmanın uzantısı olarak dünyamızı şekillendirmiştir. Bu doğrultuda bugünkü siyaset ve yaşanan gelişmeler, II. Dünya Savaşı ve sonrasına meydana gelen gelişmelerin etkisiyle ortaya çıkmıştır. II. Dünya Savaşı'nı ortaya çıkartan gelişmeler arasında Japonya'nın Asya-Pasifik bölgesindeki yayılmacılığ1 oldukça önemli bir etken olmuştur. Hatta Japonya yayılmacılığının II. Dünya Savaşı'nın başlangıç tarihi olduğu dahi ifade edilmektedir. ${ }^{1}$

Avrupa merkezli tarih anlatıcılığında Japonya'nın iki dünya savaşı arası dönemde meydana getirdiği gelişmeler, II. Dünya Savaşı'nın gerekçelerinden olmakla birlikte, Almanya ve İtalya'dan sonra Japonya üçüncü sırada ve daha tali bir rolde görülmektedir. Japonya'nın 1905'te Rusya karşısında kazandı̆̆ı galibiyet sonrası başlattığı Japon yayılmacılığı I. Dünya Savaşı sırasında Almanya'nın Uzakdoğu sömürgelerini elde etmesiyle sürmüştür. I. Dünya Savaşı sonrasında Japonya'da hızla artan nüfus dengesinin simetrik bir biçimde Japonya'nın doğal kaynakları ile orantılanamaması, sürekli artan Japon nüfusunu beslemek üzere, Japonya’nın Çin, Mançurya, Moğolistan gibi yerlere yönelmesine neden olmuştur. Japon iç politikasının meydana getirdiği militarist zihniyetin kamuoyunu yanına almasıyla birlikte had safhaya çıkan emperyal arzular, Japonya'nın işgal faaliyetleri göstermesine yol açmıştır. 1931 yılında Mançurya’yı işgal eden Japonya, daha sonra iç karışıklıklar içerisinde bulunan Çin’e yönelmiştir.

Doğrudan temas ettiği bir alan olmamakla birlikte Türkiye, dış politikası gereği dünyada meydana gelen her önemli konuyu değerlendirerek ele almıştır. $\mathrm{Bu}$ doğrultuda Türk yetkililer tarafindan savaş çıkarması muhtemel bulunan Uzakdoğu, Japon- Çin meselesi de ele alınarak dikkatle takip edilmiştir. Türkiye, uluslararası hukuk, dünya diplomasisi ve dâhil olduğu Kellog Paktı ile Milletler Cemiyeti gibi oluşumlar sebebiyle konuyu yakından izlemiştir.

\section{Dünya Savaşı Öncesinde Asya'da Meydana Gelen Gelişmeler}

Dünya tarihinde oldukça önemli bir paradigma değişikliği meydana getiren I. Dünya Savaşı'ndan tarihsel olarak kısa sayılabilecek bir süre sonra yeni bir dünya savaşı daha yaşanmıştır. Her ne kadar II. Dünya Savaşı 1939 yılında başla-

1 Sabiha Sertel, II. Dünya Savaşı Tarihi, İstanbul, Cumhuriyet Kitapları, 2009, s. 54. 
sa da savaşa neden olan gelişmeler 1939 yılından çok daha önce başlamıştır. Bu doğrultuda Eric J. Hobsbawm II. Dünya Savaşı'nın somut nedenlerinin üç gücün saldırganlığı sonucunda ortaya çıktığını belirtmiştir. Hobsbawm bu üç gücü, Mançurya'y1 işgal eden Japonya (1931), Habeşistan'ı işgal eden İtalya (1935), İspanya İç Savaşı'na müdahale eden Almanya-İtalya (1936-39) ve Avusturya'yı işgal eden Almanya (1938) olarak ifade etmiştir. ${ }^{2}$ Avrupa' da meydana gelen olaylar, Avrupa merkezli bakış açısı tarafından daha merkezi gelişmeler olarak kaydedilirken, Asya'da yaşananlar nispeten II. Dünya Savaşı tarihine giden süreçte tali bir konu olarak değerlendirilmektedir. Fakat ilginç bir biçimde Sabiha Sertel farklı bir bakış açısıyla, II. Dünya Savaşı'nın Japonya'nın Mançurya'yı işgali ile başladığını ifade etmiştir. ${ }^{3}$

Asya'daki gelişmelerin ortaya çıkmasında Japonya'nın XVI. yüzyıldan itibaren ortaya koyduğu yayılma isteği etkili olmuştur. Tokugawa Dönemi olarak nitelendirilen uzun bir dönem boyunca ada ülkesi olma konumunu kullanarak izole bir yaşam süren Japonya, Meici Döneminde uygulanan reformlar sayesinde, değişmeye ve açılmaya başlamıştır. Japonların reformlar sayesinde modern bir orduya ve yapıya kavuşması ile Japonya, Kıta Asya'sına doğru XIX. yüzyıldan itibaren yayılma eğilimi göstermiştir. Her ne kadar XIX. yüzyıl, Japonya'nın Asya’ya yönelik düşüncelerini gösteren önemli bir dönüm noktası ise de Japonlar henüz XVI. yüzyılda Kore'yi işgal etmeye yönelik girişimde bulunmuşlardır. ${ }^{4}$ Çin'e karş1 1874'te Tayvan/Farmoza'ya sefer düzenleyen Japonya, 1879'da Okinava'yı ilhak etmiş, yine aynı dönemde Rusya ile de bir antlaşma yaparak Kuril Adaları'nı ele geçirmiştir. Murat Belge'ye göre Meici rejiminin kurulmasından on y1l sonra Japonya, kabına sığmakta zorlanmaya başlamıştır. Çin'den sonra Rusya ile mücadele etmeye başlayan Japonya, Kore meselesi sebebiyle 1904'te Rusya ile savaşa tutuşmuş, 1905 'te ise Japon-Rus Savaşı, Japonya'nın dikkat çekici başarısı ile son bulmuştur. Savaş neticesinde Kore'yi himayesine alan Japonya, Çin'i ve Rusya'yı yenmesi sebebiyle büyük devlet olarak anılmaya başlanmıştır. ${ }^{5}$

1905 Asya için oldukça önemli bir kırılma anına işaret etmektedir. 1905’ten sonra Asya-Pasifik bölgesinde Avrupalı devletlerin rolü azalırken bunun yerine Japonya, Rusya ve ABD’nin rolü artmıştır. Her üç devletin Asya-Pasifik'e yönelik

2 Eric Hobsbawm, Kısa 20. Yüzyıl 1914-1991 Aşırılıklar Çağl, çev. Yavuz Alogan, İstanbul, Sarmal Yayınevi, 1996, s. 51.

3 Sabiha Sertel, a.g.e., s. 54.

4 Hasan Kösebalaban, "Japon Grand Stratejisi: Yirminci Yüzyıl Japon Dış Politikasında Süreklilik ve Değişim”, Divan, cilt 3, sayı 5, 1998, s. 67.

5 Murat Belge, Militarist Modernleşme Almanya, Japonya ve Türkiye, 2. bs., İstanbul, İletişim Yayınlar1, 2012, s. 399401-. 
politikalarının olması, üç devletin bölgede karşı karşıya gelmesine yol açmıştır. ${ }^{6}$ Japonya'nın özellikle Rusya karşısında kazandığı galibiyet, I. Dünya Savaşı öncesinde Japonya'nın emperyal politikaları için oldukça önemli bir motivasyon sağlamıştır. Savaş başladıktan sonra Japonya, Rusya ile ittifak içerisine giren İngiltere'nin yanında savaşa dâhil olmuştur. Japonya, I. Dünya Savaşı sırasında Avrupa'daki kargaşadan yararlanarak Almanya'nın sömürgelerini ele geçirerek topraklarını genişletmiştir. Japonya, savaş içerisinde ayrıca Çingtao sebebiyle Çin'le karşı karşıya gelmiş, bu durum ise Çin'in Japonya'nın himayesi altına girmesini engellemek üzere ABD’nin devreye girmesine yol açmıştır. Savaş sona erdiğinde ise Japonya galip devletler safında ABD, İngiltere, Fransa ve İtalya ile birlikte yer almış ve Milletler Cemiyeti'nin kurucularından birisi olmuştur. ${ }^{7}$

Rifat Uçarol'a göre, Japonya I. Dünya Savaşı'ndan sonra Uzakdoğu'nun en güçlü devleti haline gelmiştir. ${ }^{8}$ Japonya'nın Asya' da çok güçlü bir konuma gelmesi, yakın tarihte savaştı̆̆ 1 Çin'e yönelmesine yol açmıştır. ${ }^{9}$ Çin'de ise bu esnada tıpkı daha önce olduğu gibi yine iç karışıklıklar yaşanmaktaydı. Oral Sander, 1839 ile 1911 yılları arasındaki dönemi Çin açısından "uygarlığının çözülmesinin öyküsü” olarak değerlendirmiştir. XIX. yüzyıl boyunca Çin'de yaşanan gelişmeler (Afyon Savaşı, Taiping Ayaklanması, Boxer Ayaklanması) Çin'in izole yaşama isteğine son vererek Avrupalı devletlerin daha çok etkisi altına girmesine yol açmıştır. ${ }^{10}$ Çin'in XIX. yüzyılda yaşadıkları XX. yüzyılın başlarında da büyük bir oranda devam etmiştir. 1912 yılında cumhuriyetin ilan edilmesi, Çin'de suların durulmasına neden olmadığ gibi daha fazla siyasi kargaşa yaşanmasına neden olmuştur. Pekin, bu dönemde siyasi çekişmelerle boğuşurken Çin'in kıyı kesimleri ise büyük devletlerin yönetimi altına alınmıştır. 1925 yılına kadar sürekli el değiştiren Pekin Hükûmeti, Sun Yat Sen'in önderliğinde milliyetçi hareketin başlamasına kadar devam etmiştir. Milliyetçi hareket Çin'de sükûneti sağlamışsa da 1925 'ten sonra bu kez de Komünistler ve Milliyetçiler arasında çatışmalar başlamıştır. ${ }^{11}$

6 Oral Sander, Siyasi Tarih 1918-1994, 5. bs., Ankara, İmge Kitabevi, 1996, s. 63.

7 Belge, a.g.e., s. 404-406.

8 Rifat Uçarol, Siyasi Tarih (1789-1999), 5. bs., İstanbul, Filiz Kitabevi, 2000, s. 536.

9 Japonya, I. Dünya Savaşı'nda bile Çin aleyhine olmak üzere faaliyet göstermiş, Çin'deki Alman müstemlekelerine sahip çıkarak Çin Hükûmetine 21 maddelik teklifi kabul ettirmiştir; Bknz, M. Salih Mercan, "II. Dünya Savaşı Öncesinde Çin-Japon Münasebetlerinde Mançurya (1931)”, Yüzüncü Yıl Üniversitesi Sosyal Bilimler Enstitüsü Dergisi, say1 30, 2016, s. 325-348.

10 Oral Sander, Siyasi Tarih İlkçağlardan 1918'e, 12. bs., Ankara, İmge Kitabevi, 2003, s. 271 275.

11 Sander, a.g.e., s. 63-64. 
I. Dünya Savaşı'ndan sonra Uzakdoğu'daki en önemli güç haline gelen Japonya; ABD, SSCB ve İngiltere için Asya çıkarları açısından oldukça önemli bir tehdit olarak kabul edilmiştir. Japonya'da militarizmin etkisiyle ortaya çıkan görüşe göre dünyanın huzur ve sükûn bulması için hiyerarşiye dayanan bir idarenin tesis edilmesi lazımdır ve bu ise ancak Japonya ile mümkün olacaktır. Japonya, hiyerarşik düzen gereği harekete geçerek "geri kalmış olan Çin'i”" uyandırmak zorundayd. Bunun içinse Japonya'nın ABD, İngiltere ve SSCB'yi bu bölgeden çıkartması gerekiyordu. ${ }^{12}$ Hedefleri gereği Asya Pasifik bölgesinde Japonya'nın belirgin bir büyüme hırsı göstermesi ve bu doğrultuda Japon donanmasının büyümesi, ABD ve İngiltere için oldukça rahatsız edici olmuştur. Çıkar mücadelesi içerisinde Japon-ABD/İngiliz çatışması, II. Dünya Savaşı başlamadan çok önce I. Dünya Savaşı'nın bitmesiyle birlikte başlamıştır. ${ }^{13}$ Çin ise bu doğrultuda Japonya ile diğer ülkeler arasındaki gerginliğin önemli bir sebebi olmuştur. Henüz 1922 yılında Washington'da gerçekleşen Deniz Silahlanması Konferansı'nda Çin hakkında imzalanan antlaşmalarla Çin'e karşı uygulanacak politikalarla Japon donanmasının sınırlanması, Japonya'nın Çin üzerindeki yayılmacı emellerini frenleyen bir etken olmuştur. Japonya' da iktidarda bulunan Liberal Parti'nin Çin'e karşı aynı yı1, "yumuşak politika" izleme kararı alması, Çin ve Japonya arasında uzun bir zaman sonra olumlu ilişkilerin başlamasına yol açmıştır. Fakat Washington'da imzalanan antlaşmaların Japonya'nın yayılmasını arzu eden siyasi aktörleri özellikle de askerleri memnun etmemesi, Japonya'nın Çin'e karşı sürdürdüğü "yumuşak politikanın” 1927 yılında sona ermesine neden olmuştur. Japonya'da kabinenin değişmesi sonrasında yeni militarist hükûmetin yayınladığı Tanaka Memorandumu ile Japonya'nın Uzakdoğu'daki varlığı için Çin'in ele geçirilmesi zorunlu görülmüştür. Bunun için ilk adım olarak Mançurya'nın ve Moğolistan'ın işgali ve ABD'nin “ezilmesi” gerektiği ifade edilmiştir. "Pozitif politika” olarak ifade edilen bu politika ile birlikte Japonya'nın Çin'le olan münasebetleri gerginleşmiştir. Çin'in 1925 sonrası Milliyetçilerin önderliğinde Çin'de birlik sağlama girişimleri ise "pozitif politika" açısından hoş karşılanmayarak Japonya'nın 1927 ve 1928 'de Shantung'a iki kez asker çıkarmasına yol açmıştır. ${ }^{14}$

\section{Mançurya Savaşı ve Çin'in İşgali}

İki dünya savaşı arası dönemde Japonya'da ekonomi ve nüfusla ilgili olarak meydana gelen gelişmeler, Japonya'nın Asya'ya yönelik yayılmacı politikaları-

12 Ruth Benedict, Krizantem ve Kılıç Japon Kültürü Üzerine Bir İnceleme, çev. Türkân Turgut, İstanbul, İş Bankası Kültür Yayınları, 2011, s. 18.

13 Belge, a.g.e., s. 416-417.

14 Fahir Armaoğlu, 20. Yüzyıl Siyasî Tarihi 1914-1995, Alkım Yayınevi, s. 232-233. 
nın uygulanmasına neden olan önemli gelişmeler arasında olmuştur. $\mathrm{Bu}$ doğrultuda I. Dünya Savaşı sonrasında, ölüm oranının büyük bir oranda düşmesinden kaynaklı olarak ciddi bir artış kaydeden Japon nüfusu karşısında yönetici sınıf, sürekli artan nüfusu doyurmak üzere yetersiz kalan kendi topraklarının dışında "yaşam alanı" talep etmeye başlamıştır. ${ }^{15}$ Keza 1929 yılında patlak veren Ekonomik Buhran da Japon ekonomisini kötü bir şekilde etkilemiştir. Ekonomik sorunlar, liberal politikaların yerine, çözüm için yayılmanın kaçınılmaz olduğunu savunan militarist görüşün Japon toplumunda yaygınlık kazanmasına neden olmuştur. ${ }^{16}$ Japonya' da ekonomik temelli yaşanan gelişmelerle birlikte değişen siyasi yap1, Japonya'nın 1931 yılından 1945 y1lına kadar olan sürede savaşmasına yol açmıştır. ${ }^{17}$ Japonya'nın rakiplerine göre erken başlayan savaş macerası, ilk hamlesini Asya'da, Çin’e doğru gerçekleştirmiştir. 1905 yılında manda altına alınan Kore, 1910 yılında ise Japon işgaline uğramıştır. Japonya’nın Kore’den sonraki hedefi ise Mançurya olmuştur. ${ }^{18}$ Çin'in iç çatışmalarla zayıflayan otoritesinden yararlanan Japonya, 1931 yılından itibaren, Asya'da nüfuz sahibi olmak üzere Mançurya'ya yönelik saldırgan bir politika izlemeye başlamıştır. ${ }^{19}$

Yüzölçümü $1.416 .000 \mathrm{~km}^{2}$, nüfusu ise 30 milyon civarında (1931) olan Mançurya, tarım, orman ürünleri ve maden kömürleri açısından oldukça önemli ürünlere sahip bir bölgeydi. Mançurya'da yetişen ya da çıkartılan ürünlerin 1931 yıl1na kadar en önemli alıcısı Japonya olmuştur. Gerek sanayisi için gerekse ihtiyaç duyduğu diğer alanlar için Mançurya, Japonya’nın kuvvetlenmeye başladığı ilk dönemlerden itibaren dikkatini çekmiştir. 1905 yılında Rusya'yı yenerek Mançurya'dan çıkartan Japonya, bölgede Rusların yerini almış ve geniş bir ekonomik faaliyete girişmiştir. Japonya, Mançurya üzerindeki denetimini sağlamak ve kuvvetlendirmek üzere demiryolları yaparak işletmeye (Güney Mançurya Demiryolu Şirketi) başlamıştır. Demiryolu ağı sayesinde Japon nüfuzu kısa bir süre içerisinde hızla artmıştır. ${ }^{20}$ Japon ekonomik yatırımları ve faaliyetleri, 1930'lu yıllar boyunca ciddi bir oranda artış göstermiştir. ${ }^{21}$

15 Yves Lacoste, Büyük Oyunu Anlamak Jeopolitik: Bugünün Uzun Tarihi, 2. bs., NTV Yayınları, 2008, s. 160-161.

16 Liddell Hart, II. Dünya Savaşı Tarihi Cilt I, çev. Kerim Bağrıaçı, Yapı Kredi Yayınları, s. 219.

17 Belge, a.g.e., s. 416-417.

18 Clive Ponting, Yeni Bir Bakış Açısıyla Dünya Tarihi, çev. Eşref Bengi Özbilen, Alfa Yayınları, 2011, s. 689.

19 Hart, a.g.e., s. 213.

20 Armaoğlu, a.g.e., 231-232.

21 Kaoru Sugihara, Japan, China, and the Growth of the Asian International Economy, 1850 1949, ed. Kaoru Sugihara, vol I, Oxford University Press, 2005, s. 7. 
Fahir Armaoğlu, Japonya'nın Mançurya' daki ekonomik faaliyetlerinin işgal için Mançurya'y1 "olgun bir meyva" haline getirdiğini ifade etmiştir. Armaoğlu'na göre bütün mesele artık şartların uygun olduğu ilk anda, "bu meyvayı koparmaya" kalıyordu. ${ }^{22}$ Japonya'nın Mançurya'yı işgal etmesi için gerekli bahaneyi ise "Mukden Olayı" meydana getirmiştir. Mukden Olayı ile birlikte 1931 y1lının Eylül ayında Japon askerleri Mançurya'ya girmiştir. ${ }^{23}$ Japonya, işgal öncesinde Mançurya'nın bir kısmına yerleşmiş olsa da Mançurya topraklarının büyük kısmı Zhang Zuolin adındaki kişinin elindeydi. Zuolin'nin suikast sonucu ölmesi, istenilenin aksine Japonya'nın Mançurya' da yeni yerler ele geçirmesi sonucunu doğurmamıştır. ${ }^{24}$ Zuolin suikastı Japonya'nın Mançurya işgaline ilişkin umutları boşa çıkartarak Çin'in milliyetçilik davasını canlandırmıştır. ${ }^{25}$ Zuolin'den sonra Mançurya'da Zuolin'in oğlu vasıtasıyla Çin'in etkisini arttırması ile birlikte Japon birlikleri, Güney Mançurya'da yer alan Mukden'de sorumlusu oldukları bir patlama sonrası, -patlamanın Çinliler tarafından yapıldığını iddia ederek- Mukden'i işgal etmişlerdir. Japonya'nın Kore'de bulunan ordusu ise hükûmete danışmadan 1932 yılında Mançurya'ya girmiştir. ${ }^{26}$

1 Mart 1932 yılında ise Mukden'de Japon yanlısı Mançuryalı liderlerin de katıldığı bir kongre ile bağımsız bir Mançuko Devleti' nin kurulduğu ilan edilmiştir. Mançuko Devleti'nin sınırlarının içerisine Çin'e ait olan Jehol eyaleti de dâhil edilmiştir. Japonya, 1933 yılının Şubat ayında ise fiilen Jehol'ü işgal ederek topraklarına katmıştır. Mançurya'nın işgali sonrasında, Milletler Cemiyeti'nin herhangi bir yaptırımda bulunamadığı görülmüsștür. Yapılan bazı girişimler ise Japonya'nın yayılmacılığını durdurmaktan çok uzak olmuştur. Japonya'nın Jehol'ü işgali sonrasında da Milletler Cemiyeti'nin bir netice alamaması üzerinde Çin, Japonya ile anlaşarak işgali tanımak zorunda kalmıştır. 27 Mart 1933 tarihinde ise Japonya, Milletler Cemiyeti'nden çekilme kararı almıştır. 1935 yılında ise Sovyet Rusya, 1907 tarihli Rus-Japon Antlaşması ile Kuzey Mançurya'da sahip olduğu Doğu Çin Demiryolları'nı, Japonya ile bir çatışmaya girmemek üzere 1935 yılında Mançuko Devleti'ne satmıştır. ABD ise Japonya ile sürtüşme içerisine girmişse de ABD'nin de Mançurya konusunda tek başına bir netice elde edemediği görülmüştür. ${ }^{27}$

22 Armaoğlu, a.g.e., s. 232.

23 Hart, a.g.e., s. 213; Erdem Karaca, "T.C. Hariciye Nezareti Siyasi Istihbarat Servisi Raporlarında Mançurya Meselesi ( 1932 - 1933 )", Sosyal Bilimler Tarih ve Sanat (Bilimsel Araştırmalar Kitabı 2018), ed. Osman Köse, Ankara, 2018, s. 206.

24 Belge, a.g.e., s. 412-413.

25 Janet E. Hunter, Modern Japonya'nın Doğuşu 1853 'ten Günümüze, çev. Müfit Günay, İmge Kitabevi, 2002, s. 373.

26 Belge, a.g.e., s. 413.

27 Armaoğlu, a.g.e., s. 234-236. 
Japonya'nın Mançurya'yı işgali, II. Dünya Savaşı öncesindeki önemli kırılma anlarından bir tanesi olmuştur. Washington Deniz Silahları Konferansı ile askıya alınan Asya-Pasifik mücadelesi yeniden başlamıştır. Mücadele, II. Dünya Savaşı'nın başlaması sonrasında Japonya'nın Pearl Harbor'da ABD'ye saldırması ile doruk noktasına ulaşmıştır. ${ }^{28}$ Japonya'nın Mançurya ve Jehol'ü işgal etmesi, Japonya için yeterli olmamış, 1932 yılından itibaren Çin'in içlerine doğru ilerlemeye başlamıştır. 1934 yılında Japonya ile Çin arasında bir anlaşma yapılarak iki ülke arasında bir süre sükûnet sağlanmışsa da 1935 yılından sonra Japonya tekrar Çin'in içlerine doğru harekete geçmiştir. ${ }^{29}$ 1931-1945 yılında Japonya'nın sürekli savaştığı tek Asya ülkesi Çin olmuştur. 1935 yılından sonra yeniden harekete geçen Japonlar, Çin kentlerini işgal etse de coğrafi büyüklük nedeniyle işgal edemedikleri bazı yerlerde, direnen unsurlara karşı mücadele etmek zorunda kalmıştır. 1937 y1lında ise Japon ordusu, Milliyetçi Çin'in başkenti olan Nanjing / Nankin'i ele geçirmiştir. Japon işgali sırasında Nankin'de askerler dışında asker olmayanların da yer aldığg 300.000 kişinin katledildiği ifade edilmektedir. ${ }^{30} 1937$ 'den sonra Japon ordusu kısa sürede Çin'in doğu bölgesinin neredeyse tamamını işgal etmiştir. ${ }^{31}$ Japonlar, Çin'in tüm kıyı bölgelerini denetim altına alırlarken Çan Kay-Şek liderliğinde Milliyetçiler, kuzeye çekilmek zorunda kalmıştır. Keza Mao Zedung yönetimindeki Komünistler de Rus sınırına yakın kuzeybatı bölgesinde üslenmişlerdir. Japonlar, 1945'te yenilip birliklerini Çin'den çekmelerine kadar gerek Milliyetçiler gerekse Komünistler bulundukları bölgede kalmışlardır. ${ }^{32}$

\section{Türk Dış Politikası ve Asya'da Yaşanan Gelişmeler}

Türkiye ile Osmanlı Devleti arasında tarihsel sürekliliğin devam ettiğini gösteren en somut alanlardan birisi diplomasi geleneğinin kesintisiz bir biçimde Osmanlı Devleti'nden Cumhuriyet devrine intikali olmuştur. III. Selim Dönemi ile başlatılan diplomasi geleneği İsmail Soysal'a göre, Cumhuriyet devrinde hızla gelişmiş ve duraksamaya uğramadan bugünkü çağdaş düzeye ulaşmıştır. ${ }^{33}$ XVIII. yüzyıla kadar "eman sistemi” -gelişmelere bağlı olarak- Osmanlı diplomasisinin temel prensibi iken XVIII. yüzyılla birlikte mütekabiliyete dayanan bir diploma-

28 Sander, a.g.e., s. 65.

29 Uçarol, a.g.e., s. 536.

30 Belge, a.g.e., s. 422-423.

31 Lacoste, a.g.e., s. 172; Wolfram Eberhard, Çin Tarihi, Ankara, Türk Tarih Kurumu Basımevi, 1995, s. 357-358.

32 William H. McNeill, Dünya Tarihi, çev. Alâeddin Şenel, 6. bs., İmge Kitabevi Yayınları, 2002, s. 704705-.

33 Çağdaş Türk Diplomasisi: 200 Ylllık Süreç, Ankara, Türk Tarih Kurumu Basımevi, 1999, s. XI. 
siye geçilmek durumunda kalınmıştır. ${ }^{34}$ XVIII. yüzyıldan itibaren düşmanlarına karşı tek başına mücadele edemeyen Osmanlı Devleti, Avrupa devletleri arasında dengeyi meydana getiren unsurları takip etmek ve bunlardan faydalanmak üzere ilk daimi elçiliklerini açarak Avrupa'daki gelişmeleri değerlendirmeye başlamıştır. ${ }^{35}$ Osmanlı Devleti'nin nispeten geç intibak ettiği yeni diplomasi usulü, XX. yüzyıla gelindiğinde devletin çıkarları gereği her gelişmeyi yakından takip etmesini gerektirmiştir. Bu konuda Baskın Oran, 1920 yılında Osmanlı hariciyesinin "o kadar işinin arasında, Finlandiya ile İsveç arasındaki Aland Adaları sorununda Milletler Cemiyetinin arabuluculuk yapması konusunu Paris'teki Osmanlı temsilcisinden öğrenmek" istediğini ortaya koymuştur. ${ }^{36}$

Osmanlı diplomasi geleneğinin bir anlamda mirasçısı olan Türkiye Cumhuriyeti kendisine tevarüs eden mirasın gereği olarak dünyadaki her gelişmeyi yakından takip etmiştir. Türkiye Cumhuriyeti'nin Lozan Antlaşması'nı imzalanması sonrasında izlediği diş politika, mevcut anlaşmalara riayet eden bir pozisyondadır. Mevcut anlaşmaları kesin bir biçimde tanıyıp uygulayan Türkiye, kendi çıkarına aykırı olan durumlarda ise tek yanlı uygulamalara yanaşmamış, mevcut sorunları devletlerarası hukuk çerçevesinde gündeme taşımıştır. ${ }^{37}$ II. Dünya Savaşı öncesinde Asya' da meydana gelen gelişmeler karşısında Türk dış politikası, doğrudan çıkarı olmadığı Çin-Japonya gelişmeleri karşısında, her iki ülke nezdinde de diplomatik temsilcileri vasıtasıyla yaptığ 1 girişimler neticesinde, aralarındaki meseleyi barışçıl yollardan halletmeleri konusunda çağrıda bulunmuştur. ${ }^{38}$ Mançurya krizinden sonra ise Türkiye'nin izlediği temel politika, yeni dâhil olduğu Milletler Cemiyeti içerisinde -1934 yılında Çin'le bir Dostluk Antlaşması imzaladıktan sonra- Çin'in toprak bütünlüğünü savunmak olmuştur. Japonya konusunda ise uluslararası dayanışma içerisinde kalarak çözüm için aracı olmak istemiştir. Hasan Köni'ye göre Türkiye'nin Çin'i desteklemesine etki eden temel etken SSCB'nin Japonya'nın yayılmasından duyduğu rahatsızlık olmuştur. ${ }^{39}$

34 Mehmet İpşirli, “Osmanlı Devletinde ‘Eman’ Sistemi”, Çă̆daş Türk Diplomasisi: 200 Yıllık Süreç, Ankara, Türk Tarih Kurumu Basımevi, 1999, s. 3.

35 Ali İbrahim Savaş, Osmanlı Diplomasisi, İstanbul, 3F Yayınevi, 2007, s. 17.

36 Baskın Oran, “Lozan'ın Öncülü Bir Onur Anıt1: Müttefiklerin Sevr Barış Antlaşması Tasarısına Osmanlı Hariciyesinin Yanıtı”, Çağdaş Türk Diplomasisi: 200 Yıllık Süreç, Ankara, Türk Tarih Kurumu Basimevi, 1999, s. 262.

37 Cemil Koçak, Türk-Alman İlişkileri (1923-1939) İki Dünya Savaşı Arasındaki Dönemde Siyasal, Kültürel, Askeri ve Ekonomik İlişkiler, 2. bs., Ankara, Türk Tarih Kurumu Yayınları, 2013, s. 97.

38 Yonca Anzerlioğlu, “Tokyo Türk Maslahatgüzarının Değerlendirmeleriyle Mançukuo Devleti (1931-1933)”, Ankara Üniversitesi Türk inkılâp Tarihi Enstitüsü Atatürk Yolu Dergisi, say1 41, May1s 2008, s. 9.

39 Hasan Köni, “Genel Dış Politika Işı̆̆ında Cumhuriyet Dönemi Uzak-Doğu İlişkileri: 1933- 


\section{SSCB-Çin İhtilafı ve Türkiye}

Türk dış politikası için II. Dünya Savaşı öncesinde Japonya'nın Mançurya'ya saldırması ve "kukla bir devlet" kurması ile Çin'in Jehol eyaletini işgal etmesi, Milletler Cemiyeti'nin durumunu sorgulatırken, sonraki süreçte yaşanan diğer gelişmeler, Türkiye'nin endişelerini daha da arttırmıştır. ${ }^{40} 1935$ yılına hatta Mançurya işgaline gelmeden çok daha önce Türkiye, diplomasisi gereği Japonya ve Çin ile ilgili gelişmeleri yakından takip etmiştir. Henüz 1920'li yılların sonunda, Japonya-Çin ilişkileri değerlendirmeye alınmıştır. Tokyo Konsolosluğu'ndan ${ }^{41}$ gönderilen raporda, Japonya'nın Çin-Sovyet ihtilafı konusunda nasıl bir tutum takındığı değerlendirilmiştir. Raporda Japonya'nın iki devlet arasındaki ihtilaf konusunda kendisine bir rol atfettiği kaydedilmiştir. Ayrıca Japonya'nın Çin'in Sovyetler karşısında milli gayelerini elde edemeyerek zayıf kalmasını istediği de raporda husussen belirtilmiştir. Sovyetlerin Çin'e karşı hareketinde Japonya'nın taraftar gözüktüğünü ifade eden rapora göre Japonya, "aksayışark sulhunun idamesinde kendisinin mühim bir âmil olduğunu ve bu vesile tanınmasını istihdaf eylemektedir." ${ }^{42}$

Tokyo Elçiliği, 1929 y1lı sona ererken gönderdiği değerlendirmeyle, ÇinSSCB ihtilafı konusunda Japonya merkezli yeni gelişmelere yer vermiştir. Değerlendirmeye göre SSCB'nin sınırdaki Çin kuvvetlerini bozguna uğratması karşısında Mançurya Hükümeti, Sovyet şartları dâhilinde müzakereyi kabul etmek durumunda kalmıştır. Çin, konuyu Milletler Cemiyeti’ne götürmek üzere Japonya'ya müracaat etmiştir. Japonya, Cemiyet üyesi olmayan Sovyetlerin ret cevabı vermesi karşısında, Milletler Cemiyeti’nin müşü̈l durumda kalacağını beyan edip Çin'in girişimini tasvip etmediğini bildirmiştir. Mançurya'nın Sovyet Rusya'ya karşı Japonya'dan yardım istemesi sonrasında ise Japon Dışişleri Bakan1, Mançurya Hükûmet başkanına Sovyetlerle anlaşmayı "yegâne müessir" vasita olarak beyan etmiştir. ${ }^{43}$

36”, Ankara Üniversitesi Türk Inkılap Tarihi Enstitüsü Atatürk Yolu Dergisi, cilt 3, sayı 11, 1993, s. 274.

40 Dişişleri Bakanlığı Araştırma ve Siyaset Planlama Genel Müdürlüğü, Türkiye Dış Politikasında 50 Yıl Montreux ve Savaş Öncesi Yilları (1935-1939), s. 4.

41 Türkiye'de 1925 yılında Japonya'da ilk konsolosluğunu açmış, konsolosluk 1936 yılında büyükelçilik haline getirilmiştir; Muharrem Turp, "Türkiye-Japonya Arasında Diplomatik İlişkilerin Yeniden Tesisi ve Siyasi İktisadi İlişkiler (19511960-)”, Atatürk Üniversitesi Türkiyat Araştırmaları Enstitüsü Dergisi, sayı 69, 2020, s. 656.

42 BCA, 30-10-0-0 / 257-729-11 Dosya Ek: 434B (Muamelat Genel Müdürlüğü)

43 BCA, 30-10-0-0 / 257-729-12 Dosya Ek: 434B (Muamelat Genel Müdürlüğü, 26.12.1929) 
Asya'nın diğer ucunda SSCB ve Çin arasında yaşanan gelişmeler karşısında Türkiye, uluslararası bir gelişme olması ve özellikle Sovyet Rusya ile yakın olan dış politikası sebebiyle, olayları yakından takip etmiştir. Olayların Japonya'yı da taraf haline getirmesi karşısında dışişleri bakanlığı yetkilileri, SSCB ve Çin arasındaki çatışmada Japonya'nın da nabzını tutmuştur. Tokyo Elçiliğinin gönderdiği yazılarda sürecin resmi bir şekilde ele alındığ açıkça Türkiye'nin görüşleri ile ilgili bir değerlendirme yapılmazken tek amaç Aksa-yı Şark olarak nitelendirilen Uzakdoğu Asya'daki gelişmelerin Ankara'ya bildirilmesi olmuştur.

1931 yılında Uzakdoğu'daki gelişmelerin hızlanması üzerine Türkiye'nin meseleyi ele alışı da değişmiştir. Japonya'nın Mançurya'da Eylül ayında harekete geçmesi sonrasında, Dışişleri Bakanlığı gelişmeleri değerlendiren raporu 20 Ekim 1931'de Başbakanlığa sunmuştur. "Rus-Çin ve Japon-Çin müsellâh İhtilâfi” adını taşıyan raporda, gelişmelerle ilgili olarak Aksa-yı Şark’ta yaşanılanlar, yalnızca Rus-Çin ve Japon-Çin meselesi olmayıp uluslararası öneme haiz bir mesele olarak nitelendirilmiştir. Türkiye'nin "Kellog Misakı"n ${ }^{44}$ imzalayan ülkeler arasında bulunması, rapora göre Türkiye'nin iki konuya kayıtsız kalmasına engel teşkil etmektedir. Türkiye'nin Sovyet Rusya ile yakın ilişkileri ise bilhassa "Çin-Rus" ihtilafı konusunun takip edilmesini gerektirmiştir. Çin-Rus meselesinde Çinlilerin mesuliyet sahibi olduğu ifade edilmiştir. 1929 ihtilafının, Ruslarla Çinlilerin ortak idare ettikleri "Şarkî Şimendifer" idaresinin Çinliler tarafindan işgal edilmesi neticesinde yaşandığı ifade edilirken bunun münferit bir hadise olmadığı, aksine Çin'in 1925 yılından beri izlediği siyasetin neticesi olduğu kaydedilmiştir. Özellikle Çan Kay Şek döneminde SSCB'ye yönelik “takip edilen tecavüzkâr" politikanın Sovyet diplomatik binalarına saldırılmasına kadar vardığ 1 belirtilmiştir. Rapor, SSCB'nin olaylara karşı sert tepki göstermemesi ve sesini çıkarmaması karşısında Çin'in "Şarkî Şimendifer" hattını işgaline "teşvike medar" olduğunu ifade etmiştir. ${ }^{45}$

\section{Türkiye Açısından Mançurya Meselesi}

Türkiye'nin, Tokyo Elçiliği'’nden gönderilen raporlarda, Japonya'nın Çin-Sovyet meselesi sırasında Çin'in karşısında bir eğilim ortaya koyduğuna dikkat çekilmişti. Japonya'nın kıta Asya'sında, Mançurya'ya ve daha sonra Çin'e

44 I. Dünya Savaş1 sonrasında barışın sürekliliğini sağlamak üzere, 27 Ağustos 1928'de Paris'te ABD, İngiltere, Almanya, İtalya, Japonya, Polonya, Çekoslovakya ve Belçika arasında imzalanan Kellogg Paktı'na Türkiye, 8 Temmuz 1929'da katılmıştır; Uçarol, a.g.e., s. 529.

45 BCA, 30-10-0-0 / 257-728-4 Dosya Ek: 434A (Muamelat Genel Müdürlügü, 20.10.1931) 
yönelik bir takım emeller beslediği henüz 1931 y1lı öncesinde kendisini SSCB-Çin meselesinde hissettirmiştir. Çin-Rus meselesinin kaynağını Çin'de gören Tokyo Elçiliği, Japon-Çin meselesinde ise ihtilafın sebebini "Pekinden ziyade Tokyoda" aramanın daha doğru olacağı ifade etmiştir. Hazırlanan rapora göre bağımsızlığını kazanması sonrasında Çin'in kaydedeceği ilerlemenin bilhassa Japonya'nın menfaatini ihlal edecek mahiyette olması, Çin'de Japonların "büyük bir rol" oynamasında "şüphe"ye yer bırakmamaktadır. Hatta Japonya'nın "Çinde dahilî muharebatın devamını öteden beri arzu ve her suretle teşvik" ettiği dahi ifade edilmiştir. Bu duruma sebep olarak ise Japonya topraklarının dağlık ve maden açısından fakir olması ile buna karşı her yıl nüfusun yaklaşık 300.000 dolayında artması karşısında, Japonya'nın adalardan başka toprağa ihtiyaç duyması gerekçe olarak gösterilmiştir. Bu durum karşısında ise Japonların yapacakları ya Çin'e doğru yayılmak ya da İngiltere'nin yaptığı gibi deniz aşırı yerlere gitmek olarak belirtilmiştir. ${ }^{46}$

Japon iç siyasi yapısını ele alan rapor, askeri sınıfın bilhassa Çin'e hâkim olmak gibi amacının olduğunu belirtmiştir. Mançurya meselesinde Japon iç politikasında yaşanan gelişmelerin önemine değinilirken askeri kanadın Mançurya'yı işgal etmek üzere yaklaşık bir seneden beri müsait bir zemin aradığı bilgisi paylaşılmıştır. Bu doğrultuda bir süredir Mançurya'ya Japon ve Koreli yerleştirmek konusunda faaliyet gösterildiği de kaydedilmiştir. Çin'de Milli Hükûmetin kurulmasından sonra Mukden'in Nankin'e yaklaşması ve Nankin'de ise İngiltere ve ABD'nin nüfuz kazanması, Tokyo'da endişe meydana getirmiştir. Tüm bunlara ilaveten Çin'in Mançurya'da yeni bir demiryolu hattı ile Hulutao Limanı'nı inşaya başlamalarının Japon demiryolu ve limanına darbe indirecek olması, Japonya nezdinde Çin'in ve bilhassa Çin'in Mançurya politikasının memnuniyetsizlik oluşturmasına neden olmuştur. ${ }^{47}$

Japonya'nın Mançurya işgalini Mukden öncesi sağlayan bir takım gelişmeler meydana gelmiştir. Bu doğrultuda Mançurya'da yaşayan Japonların Mançurya yönetiminden şikâyetçi olmaları, Japon işgali için gerekçe olarak ortaya çıkan unsurlardan olmuştur. Keza Moğolistan'a ilmi gezi yapmak gerekçesiyle yola ç1kan Yüzbaşı Nakamura'nın Çin askerleri tarafından katledilip yanında bulundurduğu yüklü miktardaki paranın gasp edilmesi, Japonya'da infiale neden olmuştur. Rapora göre ise Nakamura'nın cinayeti iddia ettikleri gibi Japonların aleyhinde siyasi bir suikast değil, adi bir cinayettir. Basın bu süreçte kamuoyu üzerinde oldukça etkili olmuştur. Avrupa devletlerinin "kendi dertlerile meşgul olduğu 
bir sırada Japonyanın Mançuri hadisesini kasden çıkardığı” iddialarının olduğu, Türkiye'nin Bern Elçiliği tarafından dile getirilmiştir. ${ }^{48}$

Mançurya hadisesi konusunda oldukça detaylı bir şekilde hazırlanan rapor, Türkiye'nin Mançurya meselesi hakkındaki görüşünü ortaya koymuştur. Gelişmeleri tarihsel süreç ve realist bir süreç içerisinde ele alan rapor, doğrudan sınırının olmadığ 1 her iki devletle ilgili görüşünü ortaya koyarken aynı zamanda bu ihtilaf meselesinde Kellogg Paktı ile Türkiye'nin uluslararası hukuk çerçevesinde sürece dâhil olmak zorunda hissettiğini ortaya koymuştur. Bu doğrultuda Kellogg Paktı ahkâmına uygun olarak Çin ve Japonya arasındaki sorunun barışçıl bir biçimde çözülmesi için iki ülkenin de dışişleri bakanlıklarına telgraf çekilmiştir. Çin Cumhuriyeti Dışişleri Bakan Vekili Chingtun Frank W. Lee gönderdiği cevabi telgrafta, Japonya'nın girişimine karşı "adilâne, muvafik ve muslihane" bir çare aradıklarını ve davalarını Milletler Cemiyeti'ne tevdi ettiklerini ifade etmiştir. Türkiye'nin göstermiş olduğu derin alakaya teşekkür eden Lee, konunun adalet ve sulh yolluyla halli için Cenevre'de gerçekleşen müzakerelerin muvaffakiyetini temenni ettiğini ifade etmiştir. ${ }^{49}$

Japonya ise Türkiye'nin telgrafina daha geç cevap vermiştir. Konuyu üç başlık etrafında ele alan cevap metninde, ilk olarak Kellogg Paktı'nın mesuliyetinin farkında olduklarını ifade eden Japon yetkililer, giriştikleri harekâtın müdafaa olduğunu ifade etmişlerdir. Mançurya Demiryolu'nu ve Japon tebaasının hayat ve mallarını Çinlilerden korudukları ifadesine yer verilmiştir. İkinci olarak ise Japonya'nın sorunun çözümü için Çin nezdinde devreye girdiği ve yine barışçıl bir surette meselenin halli için Japonya'nın hazır olduğu ifade edilmiştir. Üçüncü olarak ise Japonya'nın Çin'in muhtelif yerlerinde defalarca Japonya aleyhinde organize tahrik eylemleri gerçekleştiği kaydedilmiştir. Japonlar aleyhindeki eylemlerin Çin'in milli amaçlarına kavuşmak üzere, Çin yetkilileri tarafından onaylandığı yine aynı yazıda belirtilmiştir. Telgrafta son olarak ise Çin'in Japon tebaasına yönelik yaptıklarının Kellogg Paktı'nın ikinci maddesine uygun olmadığı ifade edilmiştir. ${ }^{50}$

Japon-Çin Meselesini doğrudan diplomatlarının yolladığı bilgi ve değerlendirmeler vasıtasıyla takip eden Türkiye, genel eğilim açısından da Kellogg Paktı doğrultusunda barışçıl bir yönde adımlar atmıştır. Türkiye, Japon-Çin meselesinde mevcut yapının dışında ayrıca yakın diplomatik ilişkilere sahip olduğu Sovyet Rusya açısından da meseleyi değerlendirmeye çalışmıştır. Olayların sürdüğü

48 BCA, 30-10-0-0 / 257-728-4 Dosya Ek: 434A (Muamelat Genel Müdürlüğü, 20.10.1931)

49 BCA, 30-10-0-0 / 257-728-5 Dosya Ek: 434A (Muamelat Genel Müdürlüğü, 21.10.1931)

50 BCA, 30-10-0-0 / 257-728-6 Dosya Ek: 434A (Muamelat Genel Müdürlügü, 28.10.1931) 
dönemde Moskova Büyükelçisi Hüseyin Ragıp [Baydur], Sovyetlerin görüşünü öğrenmek üzere Litvinov ve Karahan'la bir görüşme gerçekleştirmiştir. Görüşmeye göre Mançurya'nın güneyindeki Japon işgalinin kuvvetlendiğini düşünen Karahan, Japonların kış için hazırlık yaptıklarını ifade etmiştir. Litvinov da Japonların Mançurya'yı kolaylıkla terk edeceklerini zanetmediğini vurgulamıştır. Hüseyin Ragıp'a göre Sovyetlerin mevcut durumdan hoşnut olmadığı barizdir. Fakat bu hoşnutsuzluk yalnız basın yoluyla ifade edilmiştir. Ona göre Sovyetler Mançurya meselesinde müdahil olmaktan kaçınmaktadır. Buna karşın Büyükelçi, SSCB'nin ABD'nin işgal karşısındaki politikasından memnun olduğunu ifade etmiştir. Keza Milletler Cemiyeti'nin tutumu ise eleştirilmiştir. Sovyet Rusya'nın Japonya'nın işgaline karşı tutumu, meselenin bir Japon-Sovyet çatışmasına dönmemesi yönünde olmuştur. Diğer taraftan Büyükelçi, Japonların da SSCB ile çatışmaya girmekten kaçındığını hatta bu doğrultuda "Şarki Çin Şimendifer" hattının Sovyetlere ait kısmının bulunduğu Kuzey Mançurya ve yine Moğolistan'ın Sovyetlerle alakalı kısımlarına işgali yaymaktan kaçındığını ifade etmiştir. Hüseyin Ragıp, ayrıca Japonya'nın Sovyetlere teminat verdiğini de belirtmiştir. Bu sebeplerle Büyükelçiye göre mevcut şartların sürmesi halinde Sovyet Rusya'nın Japon-Çin meselesine müdahalesine gerek görünmeyecektir. Büyükelçi konuyu Kellogg Paktı etrafında da görüşmüş, fakat Litvinov meseleyi SSCB'den uzaklaştırarak Paktın kurucularına havale etmiştir. ${ }^{51}$

1931 yılı sona ererken Dışişleri Bakanlığı tarafından Japon-Çin anlaşmazlığı ile ilgili olarak uzun bir rapor hazırlanarak Başbakanlığa sunulmuştur. Rapor, iki ülke arasındaki meselenin kökenini 1895 Savaşı'na kadar geri götürmüştür. Japonya’nın ilk olarak Çin karşısında kazandığı zaferle birlikte dünya sahnesinde dikkat çektiği ifade edilmiştir. Daha sonra 1905 Rus-Japon Savaşı'nı ve 1911'de Kore'nin ilhak edilişini ele alan rapora göre, Japon yayılması için Çin "mükemmel bir zemin olmuştur". Geçmişte olduğu gibi 1931 yılında da Çin toprakları "Japon emperyalizminin hedefi”ndedir; "Çin kıtası Japon sanayii için elverişli bir pazar, senede takriben bir milyon artan nüfusu için iddialarına nazaran kolay bir menfez, tevessü için de mükemmel bir sahadır." Japonya'nın amaçlarını göstermek doğrultusunda Eski Başbakan Baron Tanaka'nın İmparatora sunduğu muhtıra da bahis konusu edilmiştir; "Orta Asya'da hâkim olmak için Çin'i ele geçirmek, Çin'i ele geçirmek için de Mançuri’yi zaptetmek elzemdir. Bundan sonra Yakın Şark' a kadar bütün dünya Japonya'nın arzusuna ram olacaktır.” Tanaka, Mançurya ve Moğolistan'la başlayacağı sürecin Anadolu ve Avrupa'ya kadar dahi uzanacağını ifade etmiş̧ir; fakat bu Tanaka'nın şahsi görüşü değil milli bir 
siyasettir ve milli siyaseti "Baron Tanaka'nın kalemi değil Japonya'nın ihtiyacı tespit etmiştir." Raporda genel tarihsel süreç dışında yakın dönemde meydana gelen Washington Deniz Konferansı, Mançurya'nın tarihsel durumu, Çin ve Japonya arasındaki hukuki yapı, Japonya'nın Mançurya'daki durumu ve yatırımları, Japonya'nın nüfusu ve sahip olduğu coğrafi yapı, Mukden Olayı gibi konulardan detaylı bir biçimde bahsedilmiştir. Süreç daha ziyade iki kısımda ele alınırken, ilk kısımda Mançurya'nın işgaline kadar olan dönem Japonya'nın yayılma amaçları doğrultusunda ve bunu sağlayan gelişmeler ışığında ele alınmıştır. İkinci kısımda ise işgalin meydana getirdiği sorunlar, uluslararası ölçekte ele alınmıştır. İşgal, dünya barışını mevcut kanunlar ve anlaşmaları ihlal eden bir girişim olarak değerlendirmiştir. Japonya'nın Mançurya'yı işgali ise meşru görülmez bir hadise olarak kabul edilmiştir. Oldukça geniş kapsamlı olan rapor, gelişmeleri sürecin aktörlerinin görüşleri doğrultusunda ortaya koymuştur. Mançurya'da Japon ve Rus menfaatinin çatıştığı düşünülürken, Rus mıntıkası olan Kuzey Mançurya için Japonların hızla çalışmaya başladıklarını ifade edilmiştir. Mançurya' daki Japon işgali askeri kısmını tamamlamış olsa dahi mesele kapanmış değil aksine açı1mıştır ve Dışişleri Bakanlığının gelişmeleri "ehemmiyetle" takip edeceği bildirilmiştir. Bu doğrultuda yetkililer, gelişmeleri yeni bilgiler doğrultusunda bildireceklerini ifade ederlerken Türkiye'nin diplomatik temsilcilerinin bulundukları yerlerde edindikleri bilgileri paylaşmaları istenmiş ve "bu meseleye mütedair olacak mübahselerde bitaraf vaziyetimizin icabına göre idarei kelâm edilmesinin kaydını faidesiz addetmeyiz" ifadesi kullanılmıştır. ${ }^{52}$

Türkiye'nin işgali gerçekleştiren Japonya'yı dünya barışını tehdit eden bir yapıda görmekle birlikte konuya yönelik olarak "bîtaraf" tavrı Japonya ile ilişkilerin sürmesini gerektirmiştir. Bu doğrultuda iki ülke arasındaki pek çok diplomatik girişim sürdürülürken, Tokyo'ya askeri ataşe olarak giden "Binbaşı Rüştü”" Japonya'ya vardıktan sonra yaşadıklarını Ankara'ya bildirmiştir. Japonya'nın Türkiye'ye oldukça ehemmiyet verdiği intibaına sahip olan Ataşe, Türkiye'nin -Fevzi Çakmak'ın- kendisini Tokyo'ya göndermesinin sebebini -iki ordu arasında bilgi alışverişinde bulunmak- ve Türkiye Genelkurmay Başkanlığı'nın Japon ordusu ve milleti hakkındaki "hissiyatını" açıkladıktan sonra; Japon yetkililerin Türkiye’ye yönelik sözlerine yer vermiştir. Buna göre, Türk ordusunu öven yetkililer, “Türk, Macar ve Japon ırklarının menşe'lerini Orta Asya' dan almış bir ırk olarak mütalaa" etmişlerdir. İki milletin pek çok özellik bakımından yakın olduğunu ifade eden yetkililer, Ataşeye göre oldukça yakın bir tutum takınmışlardır. ${ }^{53}$ 
Türkiye, Japonca öğrenen bir askeri yetkiliyi tetkik faaliyetleri için Japonya'ya yollarken Çin'den ise bir süre sonra askeri bir heyet, Türkiye'de misafir edilerek Genelkurmay Başkanı Fevzi Çakmak'la görüşmüştür. Türkiye, bitaraf tavrını her iki ülke ile ilişkileri sürdürerek ortaya koymuştur. ${ }^{54}$

\section{Türkiye'nin Bakışı Çerçevesinde Mançuko’nun Kurulmasıı ve}

\section{Sonrasında Yaşananlar}

Japonya'nın 1931 yılında gerçekleştirdiği işgal sonucunda 1 Mart 1932 y1lında Mukden'de Japon yanlısı Mançuryalı liderlerin de katıldığı bir kongre ile bağımsız bir "Manchukuo Devleti"nin kurulduğu tüm dünyaya ilan edilmiştir. ${ }^{55}$ Mançuko devletinin kurulması sonrasında Türkiye'nin gelişmelerle yeniden ilgilenmeye başladığı görülmüştür. Bu doğrultuda Japon Hükûmetinin Eylül 1932 yılında yaptığı Mançuko ile ilgili açıklama Tokyo Elçiliği tarafından süratle Ankara'ya bildirilmiştir. ${ }^{56}$ Eylül ayında Japonya'nın bağımsız Mançuko'yu tanıması ile birlikte Dışişleri Bakanlığ 1 Matbuat Servisi, gelişmelerin dünya sathında nasıl yankılandığını derlemiştir. Türkiye, bir taraftan gelişmeleri Elçiliği vasıtasıyla takip ederken bir diğer taraftan ise dünya devletlerinin basınında olayın nasıl aksettiğini takip etmiştir. ${ }^{57}$

1932 y1lı sona ererken hazırlanan bir diğer raporda, Japonya ve Çin arasındaki savaş durumu ile Şangay ve Mançurya gelişmeleri ele alınmıştır. Rapora göre Şangay'da iki ülke kuvvetleri arasında Mart başında yaşanan çatışma sonrasında, Japonların Çinlileri geri çekilmeye zorlamasından sonra iki tarafın da zımni kabulü ile birlikte, Japon-Çin meselesinin siyasi devresi başlamıştır. Siyasi sürecin başladığı yeni devrede, Milletler Cemiyeti’nin aktif olduğundan bahsedilmiştir. ${ }^{58}$ Japon-Çin meselesini incelemek üzere kurulan ve ismi "On Dokuzlar Komisyonu” olarak anılan komitede, Türkiye’nin temsilcisi olarak Bern Büyükelçisi Cemal Hüsnü de görev almıştır. ${ }^{59}$

Japon-Çin meselesinde yaşananlar konunun bir diğer tarafı olan, fakat aktif bir politika gözetme kararı almayan Sovyet Rusya'nın Japonya'ya karşı Çin'le yakınlaşma içerisine girdiği, Dışişleri Bakanlığ yetkililerinin dikkatini çekmiştir.

54 BCA, 30-10-0-0 / 220-367-1 Dosya Ek: 239 (Muamelat Genel Müdürlüğü, 22.02.1934)

55 Armaoğlu, a.g.e., s. 234.

56 BCA, 30-10-0-0 / 257-729-21 Dosya Ek: 434B (Muamelat Genel Müdürlüğü, 12.10.1932)

57 BCA, 30-10-0-0 / 220-484-2 Dosya Ek: 400-3 (Muamelat Genel Müdürlügü̈, 05.11.1932)

58 BCA, 30-10-0-0 / 257-728-9 Dosya Ek: 434A (Muamelat Genel Müdürlüğü, 28.11.1932)

59 BCA, 30-10-0-0 / 257-726-4 Dosya Ek: 434 (Muamelat Genel Müdürlüğü, 03.12.1932); BCA, 30-18-1-2 / 32-74-14 Dosya Ek: 401-11 (Kararlar Daire Başkanlığ 1 , 13.12.1932) 
Moskova Büyükelçiliğgi, Rus basınına dayandırdığı bir haberle SSCB-Çin ilişkilerinin hızlandığına dikkat çekmiş ve SSCB-Çin ilişkilerinin normal seviyesine gelmesi için Cenevre'de M. Litvinov ile Çin temsilcisi Dr. Yen arasında nota teatisi yapıldığını bildirmiştir. ${ }^{60}$ Türk dış politikası açısından henüz 1931 yılında olaylar yeni gelişme kaydettiğinde, durum tespiti olarak ortaya konulan "Japon ihtilafi, Çin-Rus meselesine tesir ederek bu konunun 1slah edilmesine imkân vermiştir" görüşüne uygun olarak, 1932 yılının son günlerinde SSCB ve Çin arasındaki ilişkiler hızlanmıştır. Dışişleri Bakanlığı Matbuat Servisi, Litvinov ve Yen arasında gerçekleşen görüşmenin dünya basınında nasıl yankıladığını da yakından takip ederek özellikle Avrupalı gazetelerin görüşlerini derleyerek bir araya getirmiştir. ${ }^{62}$ Türkiye, dış politikasında oldukça önemli bir konumda bulunan Sovyet Rusya'nın Japon-Çin meselesindeki tutumunu takip etmeyi 1933 y1lında da sürdürmüştür. Moskova Büyükelçisi Hüseyin Ragıp, gönderdiği bir telgrafla Sovyet Rusya'nın Japonya'ya teklif ettiği saldırmazlık antlaşmasının Çin-SSCB yakınlaşması nedeniyle Japonya tarafından reddedildiğini bildirmiştir. Hüseyin Ragıp'a göre Japonya'nın reddi ile Çin-SSCB yakınlaşmasının daha da artması muhtemeldir. Ayrıca Büyükelçi, Japonların Mançurya işgal sahasını biraz daha genişleterek Pekin'e oldukça yakın olan ve Kuzey Çin ile Moğolistan'ın kapısı mesabesinde olan "Şan-hay Koang"ı işgal ettiğini bildirmiştir. ${ }^{63}$ Saldırmazlık antlaşması için "zamanın müsait olmadığını" ifade eden Japonya'nın bu cevabı sonrasında, müzakereler sürdürülse de bir netice alınamamıştır. Mart ayında Ankara'ya gönderilen bir istihbarat raporunda ise "Mançurideki büyük işe girişen Japonya'nın, bu firtınayı atlatabilmek için başvurduğu çarelerden en mühimi”, Japonların "Mançuri işinde Devletler istediğini yapmazlarsa her şeyin üstünde olan bu millî dilek uğruna Rusya'ya yanaşarak Pasifik meselesinde Amerika'yı yalnız bırakacağını" yaymaları olmuştur. Raporda yer alan tespite göre, Japonya, uluslararası havanın kendi lehlerine döndüğü anda Ruslarla anlaşmak fikrini kullanacaktır. ${ }^{64}$

1933 yılında Türkiye'nin Japon-Çin meselesindeki tutumunu ortaya koyan en net bilgiler, Türkiye’nin Bern Büyükelçisi Cemal Hüsnü tarafından ortaya konulmuştur. Ocak ayı içerisinde gerçekleşen "On Dokuzlar Komisyonu” toplantısına katılan Büyükelçi, komitenin Japon-Çin anlaşmazlığına dair esas hakkında tespit edilen rapordan bahsetmiştir. Raporun içeriğine dair büyük devlerle diğer devletlerin arasında ihtilaf vuku bulduğunu söyleyen Cemal Hüsnü, İngiltere'nin

60 BCA, 30-10-0-0 / 245-657-26 Dosya Ek: 429 (Muamelat Genel Müdürlüğü, 21.12.1932)

61 BCA, 30-10-0-0 / 257-728-4 Dosya Ek: 434A (Muamelat Genel Müdürlügü, 20.10.1931)

62 BCA, 30-10-0-0 / 257-726-7 Dosya Ek: 434 (Muamelat Genel Müdürlüğü, 29.12.1932)

63 BCA, 30-10-0-0 / 220-485-3 Dosya Ek: 400-3 (Muamelat Genel Müdürlüğü, 12.01.1933)

64 BCA, 30-10-0-0 / 220-486-10 Dosya Ek: 400-3 (Muamelat Genel Müdürlüğü, 14.03.1933) 
Lytton Raporu' nun ${ }^{65}$ kabul edilmesini istemesi karşısında müzakereye karışmadığını ifade etmiştir. Yine kendisinin bundan önceki müzakerelerde de "usul ve şeraite ve şekil hakkındaki bazı teklif ve beyanatla" iktifa edindiğini söyleyerek esasa girmediğini ifade etmiştir. Büyükelçiye göre, komitenin bir karara varamayacağı belli olunca oluşturulan yeni komite teşkili için harekete geçilmiştir. Milletler Cemiyeti'nin içerisinde oluşturulan bu komitelerin gelecekteki diğer meseleler için oluşturulacak komitelere dayanak olduğunu düşünen Cemal Hüsnü, komite başkanı ile toplantı sonrası görüşerek Türkiye'nin de "komiteye dâhil memleketler kadar bu meselede (alakadar) olduğunu ve rapordan mütevellit (netayiç) ile Türkiye'ye isabet edebileceği hissenin diğer bazı memleketler hissesinden aşağı olmayacağını" ifade etmiştir. Cemal Hüsnü'ye göre Türkiye'nin komiteye girmemesi raporun "On Dokuzlar Komisyonu" içerisindeki müzakere sırasında Türkiye’ye serbestlik vermektedir. Bu durum ise Çin ve Japonya’ya karşı daha uygun görülmüştür. Cemal Hüsnü, sözleri ile bundan sonra yapılacak girişimlerde ve oluşumlarda yetkililerin Türkiye'nin "ihmale tahammül edemiyeceği"ni ortaya koymuştur. ${ }^{66}$ Türkiye, diplomatik girişimlerinin yanı sıra, Çin ve Japon basını başta olmak üzere dünya basınında Japon-Çin meselesinin nasıl yankılandığını değerlendirmiştir. ${ }^{67}$

Tokyo diplomatik temsilciliğinden gönderilen 22 Şubat tarihli bir başka raporda, 1933 yılının henüz başında "Mançuri işinin" dönüm noktasında bulunulduğu ifade edilmiştir. Rapora göre Mançurya meselesi birkaç merhaleden meydana gelmektedir. Bu doğrultuda Mançuko devletinin kurulması ilk durak olarak kabul edilirken, Jehol ve İç Moğolistan'ın Mançurya'nın bir parçası sayılması ikinci durak, Mançuko devletinin fiilen ve hukuken tanınması ise üçüncü durak olarak kabul edilmiştir. Milletler Cemiyeti'nin nihai karara varmaması önemli bir sorun olarak görülmüştür. Raporda Mançurya meselesine Japon siyasi mahfillerinin nasıl baktığı da ayrıca ele alınmıştır. Buna göre, "Mutediller" Mançuko'nun bağımsızlığının dünyaca tanınması karşılığında Jehol ve İç Moğolistan'dan vazgeçmeye razıyken çoğunluk ise mezkûr alanlar olmadan kurulacak bir Mançuko'yu

65 Mançuko Devleti'nin Japonya tarafından tanınması sonrasında Milletler Cemiyeti'nin durum tespiti için kurduğu araştırma grubunun hazırladığı rapor. Lytton Raporu'nda, Mançurya'nın Çin'e bağlı otonom bir devlet olması kabul edilmiştir; Köni, a.g.m., s. 273.

66 BCA, 30-10-0-0 / 222-498-13 Dosya Ek: 401 (Muamelat Genel Müdürlüğü, 25.01.1933)

67 BCA, 30-10-0-0 / 257-726-11 Dosya Ek: 434 (Muamelat Genel Müdürlüğü, 15.02.1933); BCA, 30-10-0-0 / 257-726-15 Dosya Ek: 434 (Muamelat Genel Müdürlüğü, 25.02.1933); BCA, 30-10-0-0 / 267-802-8 Dosya Ek: 440 (Muamelat Genel Müdürlüğü, 02.03.1933); BCA, 30-10-0-0 / 257-727-2 Dosya Ek: 434 (Muamelat Genel Müdürlüğü, 09.03.1933); BCA, 3010-0-0 / 220-486-13 Dosya Ek: 400-3 (Muamelat Genel Müdürlüğü, 25.03.1933) 
bütün olarak görmemektedirler. Japon yetkililer, askeri hizip ve yine bu askeri hizip tarafından "tahrik" edilen kamuoyunun etkisindedirler, fakat vazgeçmekten başka bir durum da mümkün görülmemektedir. Ayrıca Mançuko devletinin tanınmas1 sonucunda elde edeceği kara ve deniz kuvvetine sahip olma hakkının Japonya'ya, bölgedeki iki rakibi ABD ve SSCB karşısında avantaj sağlayacağ1 vurgulanmıştır. Diğer taraftan Japonya'nın Mançurya meselesini istediği gibi halletse bile bu durumun Japon "iktisadi emellerini tatmin edebilmesi" şüpheli görülmüştür. Mançurya'da asayişi sağladıktan sonra Japonya'nın “muhaceret işindeki kabiliyetsizliklerinden" dolayı, Mançuko'ya az Japonun gideceği, dolayısıyla da Mançurya işgalinin Japon "nüfus meselesini kökünden halletmeyeceği”"nin anlaşılacağı iddia edilmiştir. Ayrıca Mançurya'dan sağlanacak hammaddelerin ilk başta Japon ekonomisine katkı sağlayacağı, fakat sonrasında ise ucuz işgücünün yol açacağ 1 rekabetin Japonya' da ciddi bir ekonomik buhrana yol açacağ da iddia edilmiştir. ${ }^{68}$ Çin'in durumunu da ele alan rapor, Çin'de yaşanan iç karışıklık sebebiyle sağlıklı bir bilgi almanın mümkün olmadığı kaydetmiştir. Fakat bazı kaynaklardan alınan bilgiler doğrultusunda Çin'i idare eden üç unsurdan bahsedilmiştir; Nankinler, Kantonlular ve herhangi bir suretle iş başına gelenler. Üçüncü gruptakileri şahsi menfaat peşinde koşanlar olarak niteleyen rapor, Kantonluları ise milliyetçi ve bağımsızlık düşüncesine sahip bir grup olarak ifade etmiştir. Kantonluların mücadeleyi, "son para ve insanı" feda edecek noktaya kadar sürdürmeyi göze aldıkları belirtilmiştir. Kantonluları önemli bir amil olarak gören rapor, Nankinlerin de aynı milli hisleri beslemekle birlikte, dışarıdan alınacak yardım neticesinde milli bir kuvvet kurma düşüncesiyle Kantonlulardan ayrıldıkları tespitinde bulunmuştur. Fakat son yaşananlar karşında Nankinlikerin de Kantonluların görüşüne döndüğü ifade edilmiştir. Rapora göre yaşanan son gelişmelere karşı, Çin'in Mançurya meselesi üzerindeki görüşü bu iki yapının birbirleriyle mücadelesi sonucunda ortaya çıkacaktır. ${ }^{69}$

Japon-Çin meselesinde Japonya ve Çin dışındaki devletlerin görüş ve çıkarları doğrultusunda diğer devletlerde ele alınmıştır. Bu doğrultuda SSCB'nin Mançurya'daki menfaatlerini siyasi yollarla müdafaa ettiği ve Moğolistan'1 Japon yayılmacılığından kurtarmak üzere bir nevi Sovyet idaresi tesis ettiği kaydedilmiştir. Japonlarla anlaşmak üzere Mançuko'yu fiilen tanıdığı belirtilen SSCB'nin “Çin Şark Şimendiferlerini”" satacağının belli olduğu ifade edilmiştir. Japonları kırmamak üzere Çin'le siyasi ilişkileri eski konumuna getirmek üzere yavaş hareket eden SSCB'nin Japonya karşısında, ABD ile anlaşmak istediği iddialarına da yer 
verilmiştir. Rapora göre iddia ve haberler doğru ise SSCB'nin ABD konusundaki tasavvuru oldukça yerinde bir karardır. Ayrıca ABD’nin Japon yayılmacılığı konusundaki tavrı da ele alınmıştır. Asya-Pasifik'te iki devletin ekonomik çıkarları çatışmakla birlikte Amerika, Mançurya için her fedakârlı̆̆ göze alan Japonya ile çatışmaktan çekinmektedir. Fakat ABD'nin bu konu hakkında hukuki çalışmaları sürdürdüğü ifade edilmiştir. İngiltere'nin Japon işgali meselesine bakışı ise Milletler Cemiyeti, İngilizlerin Hindistan politikası ve ekonomik çıkarlar ekseninde değerlendirilmiştir. ABD’nin baskısıyla Japonya ile ittifakı fesheden İngiltere, Çin'i “tutar gibi” görünmekteyse de ABD ve Japonya'yı birbirlerine yaklaştırmak istemektedir. Mezkûr devletlerin yanı sıra Japon-Çin meselesi, daha az olmakla birlikte Fransa ve İtalya devletleri ekseninde de ele alınmıştır. Son olarak ihtilaf konusu, Japonya'nın Milletler Cemiyeti'nden çıkıp çıkmayacağı yönünden ele alınmıştır. Raporda yer alan tespitlere göre Japonya Mançurya konusunu istediği şekilde halletmek üzere hazırlanmıştır. Milletler Cemiyeti'nin Japonya aleyhinde karar almasının Japon kamuoyunu harekete geçirdiği kaydedilmiştir. Raporda önemli bir öngörüde bulunularak "zamanını tayin etmek mümkün olmamakla beraber her suretle önü alınmazsa bir pasifik harbini vukuaa muhakkak nazarile bakma"nın yanlış olmayacağı ifade edilmiştir. Pasifik savaşının başlangıç noktası ise Çin-Japon meselesi olarak kaydedilmiştir. Bu sebeple Çin-Japon meselesinin dikkatle takip edildiği vurgulanmıştır. ${ }^{70}$

\section{Japonya'nın Milletler Cemiyeti'nden Çekilmesi Sonrasında Yaşanan Geliş̧meler}

Japonya'nın Mançurya'yı işgali sonrasında büyük devletlerin bir araya gelip Japonya’ya yönelik ortak ve güçlü bir tepki göstermemesi, keza Milletler Cemiyeti'nin de konuyla ilgili herhangi bir şey yapmaması, Japonya'nın Mançurya konusunda daha çok cesaretlenmesine sebep olmuştur. Fahir Armaoğlu'na göre Japonya daha serbest hareket edebilmek için 1933 yılının Mart ayında Milletler Cemiyeti'nden çekilmiştir. 1934 yılında ise Washington Antlaşmalarını feshederek tüm bağlarından kurtulmuş ve aynı tarihlerde diğer taraftan Asya'nın Monroe Doktirini'ni ortaya atmıştır. ${ }^{71}$ Tokyo Üniversitesi'nden Prof. Dr. Hikomatsu Kamikawa'nın kavramsallaştırdığı Uzakşark Monroe Nazariyesi / Asya Monroe Doktrini, Avrupa devletleri ve ABD’nin Asya üzerindeki “emperyalizmine”, "muhalefet gayesi" amacı taşımaktadır. ${ }^{22}$ Murat Belge'ye göre Pan-Asyacılık türü açıklamalar, işgal gerekçesi oluşturmanın "daha hoş tını”lı bir haliydi ve Ja-

70 BCA, 30-10-0-0 / 257-727-5 Dosya Ek: 434 (Muamelat Genel Müdürlüğü, 10.04.1933)

71 Armaoğlu, a.g.e., s. 271.

72 BCA, 30-10-0-0 / 257-727-11 Dosya Ek: 434 (Muamelat Genel Müdürlüğü, 20.05.1933) 
ponya, Asya dişındaki devletlerin elinde olan Endonezya, Birmanya, Hindistan, Malaka, Hindiçini gibi yerleri ele geçirmeyi istiyordu. ${ }^{73} \mathrm{Bu}$ doğrultuda Çin'in Milliyetçi kanadı ile Komünist kanadı arasındaki iç çatışmaların ortaya çıkardığı kargaşa, Japonya'y1 1934 yılından itibaren Mançurya ve Jehol üzerinden Çin'in diğer kuzey eyaletlerine sızmak üzere harekete geçirmiştir. 1935-1936 yıllarında Çin'in üzerindeki Japon tehdidi kendisini oldukça ciddi bir biçimde hissettirmeye başlamıştır. 1936 yılı başından itibaren duraklayan Japonya'nın Çin faaliyetleri, Japon iç ve dış politikasında yaşanan gelişmelerin etkisiyle 1937 yazına kadar durmuştur. 7-8 Temmuz 1937 tarihinde Pekin-Hankow yakınlarında yer alan Marco Polo köprüsünde Çin ve Japon askerleri arasında çıkan çatışma sonrasında Japonya, Pekin'i işgal etmiştir. Japonya'nın 26 Temmuz'da giriştiği işgal hareketi, kolaylıkla Çin'in işgaline yol açmamış, süreç II. Dünya Savaşı'nın sonuna kadar sürmüştür. ${ }^{74}$

Türkiye, Japonya'nın Milletler Cemiyeti'nden ayrılmasından sonra, Asya-Pasifik'te meydana gelecek bir savaş tehlikesi sebebiyle Uzakdoğu'daki gelişmeleri yakından takip etmeyi sürdürmüştür. ${ }^{75} \mathrm{Bu}$ doğrultuda Türkiye'nin takip ettiği konular arasında Japonya ve SSCB arasında ihtilaf konusu olan "Çin Şark Şimendifer" hattı yer almıştır. İki devlet arasında problem olan hatıı SSCB tarafindan Japonya'ya satılması uzunca bir süredir gündemdeyse de Türkiye'nin Tokyo Elçiliği, Japonya'nın değeri 100 milyon yeni bulan hattı satın alacak halde olmadığını ve yapılan anlaşmalar gereği Mançuko'nun hattı satın alması için de borç veremeyeceğini kaydetmiştir. ${ }^{76} 1934$ yılı itibariyle Avrupa' daki gelişmeler, Türkiye'nin Uzakdoğu'dan daha çok Avrupa'yı yakinen takip etmesini gerektirmiştir. Japon-Çin meselesinin nispeten gerileyen durumu, Türkiye'nin dış politikasında önceliği Avrupa'daki gelişmelere yöneltmiştir. Londra Büyükelçiliğinin 27 Nisan 1934 tarihli raporunda, Almanya-İtalya ile ilgili gelişmelerin gündemin ilk sırasında yer aldığ 1 görülmüştür. Keza Türkiye-İngiltere arasındaki ilişkilerin daha öncelikli olduğu görülmüştür. Japon-Çin meselesi ile ilgili olarak tek dikkat çeken gelişme, Japonya'nın Çin üzerinde Monroe Doktrinini tatbik etmek arzusunda olduğu ile ilgili mevzu olmuştur. ${ }^{77} \mathrm{Bu}$ doğrultuda Harici Matbuat

73 Belge, a.g.e.., s. 418-419.

74 Armaoğlu, a.g.e., s. 274-276.

75 BCA, 30-10-0-0 / 257-727-8 Dosya Ek: 434 (Muamelat Genel Müdürlüğü, 14.05.1933); BCA, 30-10-0-0 / 257-728-10 Dosya Ek: 434A (Muamelat Genel Müdürlüğü, 20.05.1933); BCA, 30-10-0-0 / 221-488-7 Dosya Ek: 400-3 (Muamelat Genel Müdürlüğü, 21.06.1933); BCA, 3010-0-0 / 257 - 727 - 9 Dosya Ek: 434 (Muamelat Genel Müdürlüğü, 14.05.1933)

76 BCA, 30-10-0-0 / 257-727-13 Dosya Ek: 434 (Muamelat Genel Müdürlüğü, 03.06.1933)

77 BCA, 30-10-0-0 / 221-490-7 Dosya Ek: 400-3 (Muamelat Genel Müdürlüğü, 14.05.1934) 
Müdürlüğü tarafindan hazırlanan başka bir raporda Sovyet Pravda gazetesine dayandırılan haberde, Japonların Çin'in kuzeyini ve iç Moğolistan'ı işgal etmek üzere harekete geçtiği bilgisi kaydedilmiştir. ${ }^{78}$

Japonya'nın yayılma arzusunu sürdürmesi karşısında Tokyo Elçiliğinden gönderilen bir raporda, İç Moğolistan konusunda Çin ve SSCB'nin anlaşma yaptığ 1 haberi değerlendirilmiştir. Türk yetkililerine göre her ne kadar iddia tekzip edilmişse de iki ülke arasında bir anlaşmanın olduğu ve şimdilik bunun açıklanmasının tehir edildiği ifade edilmiştir. Ayrıca Tokyo Elçiliği, Moğolistan meselesini kapsamlı bir şekilde ele almak ve Türkiye'nin bu konuda oluşturacağ 1 politikaya katk1 sağlamak üzere tarihsel süreci ve konjonktürel gelişmeleri ele alan bir rapor hazırlamaya başlamıştır. ${ }^{79}$

1935 yılı sona ererken Moskova Büyükelçisi Zekai Apaydın tarafından iki rapor hazırlanmıştır. "Japon Aksayışark faaliyeti -Mongolistan" adını taşıyan ilk raporda Japonya'nın sevk ve idaresi altında Kuzey Çin'in Hebey ve Cahara eyaletlerinde ilan edilen muhtariyet ile Nankin Hükûmetinin muhtariyeti tanımas1 üzerine yaşanan gelişmeler ile Moğolistan'daki gelişmeler ele alınmıştır. Yapılan anlaşma ile tanınan muhtariyetin Çin'de nasıl yankılandığı, Çin Milliyetçi kanadın ne tür tepki gösterdiği kaydedilen hususlar arasında olmuştur. Aynı şekilde Japonların Moğolistan üzerindeki nüfuzlarını genişletmeye başladıkları da kaydedilmiştir. Raporda, 1921 yılında Moğolistan Halk Cumhuriyeti ile SSCB arasında imzalanan "Dostluk Münasebetleri Tesisi” sözleşmesi ile SSCB'nin bağımsız Moğolistan üzerindeki nüfuzu ve etkisinden bahsedilmiştir. İki taraf arasında bulunan gizli bir antlaşma ile sağlanan ikili ilişkilerin, Japonya'nın Moğolistan Halk Cumhuriyeti'ne saldırması karşısında SSCB'nin sessiz kalmasına neden olmayacağı altı çizilen bir husus olmuştur. Zira Çin ile SSCB arasında yapılan anlaşma gereği, Harici Moğolistan da Çin'e ait kabul edilmektedir ve Japonya İç Moğolistan'a aksamında olan Jehol'den sonra Cahar'da da nüfuz tesis etmiştir. Zeki Apaydın, yetkili isimlerin açıklamalarına dayanarak SSCB'nin Harici Moğolistan'a (Moğolistan Halk Cumhuriyeti) yapılacak bir Japon taarruzunu sükûnetle karşılamayacakları ifadesine yer vermiştir. Apaydın'a göre İngiltere, ABD ve SSCB'yi oldukça meşgul eden Japonya'nın Uzakdoğu faaliyetleri, henüz durulmayan İtalya-Habeşistan meselesi ve Milletler Cemiyeti buhranın meydana getirdiği havayı daha da gerginleştirmekte ve her iki konu birbirini daha da şiddetlendirmektedir. ${ }^{80}$

78 BCA, 490-1-0-0 / 609-111-2 Dosya Ek: 3. Büro (Muamelat Genel Müdürlüğü, 14.05.1934)

79 BCA, 30-10-0-0 / 221-490-17 Dosya Ek: 400-3 (Muamelat Genel Müdürlüğü, 15.08.1934)

80 BCA, 30-10-0-0 / 257-727-15 Dosya Ek: 434 (Muamelat Genel Müdürlügü, 09.01.1936) 
Zekai Apaydın'ın hazırladığı ikinci rapor ise Çin'in ekonomik vaziyeti hakkında hazırlanmıştır. Rapora göre 1929 ekonomik buhranı tüm dünyada hafiflemeye başlarken, Çin'de ve Uzakdoğu'da buhran yeni yeni şiddetlenmeye yüz tutmuştur. Çin'deki son yarım yüzyıllık ekonomik süreci ele alan Apaydın, edindiği bilgiler doğrultusunda, İngilizlerin Çin'in ekonomik durumuyla yakından ilgilendiğini ifade etmiştir. İngiliz yetkili Fredric Leith Ross'un Nankin'e gerçekleştirdiği ziyaret bu doğrultuda Çin'in nakit sıkıntısına çare bulmak amacıyla gerçekleşen bir ziyaret olarak kabul edilmiştir. Apaydın, Japonların, İngiltere'nin Çin'e nakit yardımında bulunması sonrasında, Çin'in bu parayı orduya sarfederek mevcut durumu körükleyeceğini savundukları görüşüne de yer vermiştir. ${ }^{81}$ Ross'un ziyareti yalnızca Çin'in nakit sıkıntısı ile ilgili olmamış aynı zamanda Çin'in ekonomik olarak ayağa kaldırılmasını hedef almıştır. İngiltere'nin ve ABD'nin Çin'de var olan önemli yatırımları, Japon ekonomik nüfuzu karşısında tehlikeli görülmüştür. Ross, 1936 y1lında gerçekleştirdiği ikinci ziyaretle İngilizlerin tutumunu ortaya koyarken İngiltere'nin girişimi neticesinde Çin'in İngiltere nüfuzu altına gireceği, SSCB ve Japon yönetim ile gazetelerine aksetmiştir. Dışişleri Bakanlığı tarafından Başbakanlığa gönderilen raporda özellikle İngilizlerin girişimi karşısında Japonya'nın menfaat temin etmek gayesi güttüğü ifadesine yer verilmiştir. ${ }^{82}$

İtalya'nın Akdeniz' de meydana getirdiği gerilim, Türkiye'nin öncelikli olarak Akdeniz temelli bir dış politika vizyonu geliştirmesini sağlarken, İtalya'nın 1935-1936 yılında Habeşistan'1 işgal etmesi, Türk dış politikasında öncelikli meselenin nispeten Avrupa ve Akdeniz'le sınırlı olmasını gerektirmiştir. Keza İtalya'nın meydana getirdiği endişe, 1934 yılında Balkan Antantı'nı vücuda getirirken 1937 yılında yeniden Uzakdoğu'da gelişmelerin hararet kazandığı bir anda Türkiye, Balkan Antantı sonrasında ise doğudaki komşularıyla yeni bir pakt sürecini hızlandırmıştır. Buna karşın 1937 yılında Marco Polo Köprüsü olayı sonrasında başlayan işgal, basında yoğun bir şekilde işlenmiştir. Özellikle Ulus gazetesi gelişmelere çok sık bir şekilde değinmiştir. Japonya-Çin meselesi Marco Polo Köprüsü olayı ile yeniden gündeme gelirken, Türkiye yaklaşan savaş tehdidi nedeniyle önceliğini Uzakşark'tan Yakınşark'a kaydırmıştır. Sadabad Paktı çalışmalarının nihayet bulduğu bir zamanda Türkiye'nin İran, Irak ve Afganistan ile gerçekleştirdiği çalışma ve aynı zamanda İngiltere'nin dostluğu Türkiye'nin öncelikli konusu olmuştur. ${ }^{83}$ Türkiye'nin mezkûr konu dışındaki dış politikasında

81 BCA, 30-10-0-0 / 257-727-15 Dosya Ek: 434 (Muamelat Genel Müdürlüğü, 09.01.1936)

82 BCA, 30-10-0-0 / 221-492-43 Dosya Ek: 400-3 (Muamelat Genel Müdürlüğü, 02.12.1936)

83 Ulus, 7 Temmuz 1937; Ulus, 8 Temmuz 1937; Kurun, 10 Temmuz 1937; Tan, 9 Temmuz 1937; Cumhuriyet, 9 Temmuz 1937; Akşam 9 Temmuz 1937. 
önemli olan diğer hadiseler ise, İspanya İç Savaşı, Balkan Antantı, Almanya ile ticari ilişkiler, Filistin meselesi olmuştur. ${ }^{84}$ Japonya ve Çin arasında başlayan çatışma ise 9 Temmuz tarihinde gazeteler vasıtasıyla duyurulmuştur. ${ }^{85}$ Türk basını Japon-Çin meselesini duyururken konuyu daha ziyade bağımsız bir şekilde ele almıştır. ${ }^{86}$ Fakat çatışmanın Sadabad Paktı'nın gölgesinde kaldığı görülmüştür. ${ }^{87}$ Sonraki günlerde ise Japon-Çin meselesi önemli olmakla birlikte Türkiye'nin coğrafi yakınlığı sebebiyle, Almanya ve İtalya'nın dâhil olduğu olaylar, öncelikli gündem konusu olmuştur. ${ }^{88}$ Keza Türk-Sovyet dostluğu ise diğer bir önemli konu olarak görülmüştür. ${ }^{89}$ Olayların üzerinden birkaç gün geçtikten sonra İngiltere ve ABD'nin Japonya nezdinde devreye girmesiyle birlikte konu iki ülkenin bakışı ekseninde değerlendirilmiştir. ${ }^{90}$

20 Temmuz'da Ulus gazetesinde yer alan imzasız "Dış Politika" isimli köşede Japon Ordusu başlı̆g 1 altında gelişmelerin değerlendirildiği görülmüştür. Ulus'un Hükûmetin yarı resmi sözcüsü hüviyetinde olması, bu anlamda Marco Polo Köprüsü gelişmeleri sonrasında Hükûmetin görüşünün ne yönde olduğuna dair ipuçları vermektedir. Yazıda, konunun yeniden tüm dünyanın dikkatini Asya kıtasına çektiği ifade edildikten sonra, mesele "Uzak Şark buhranı" olarak isimlendirmiştir. Yazı, çatışmayı Japonya'nın genişleme ihtiyacı ile bu ihtiyacın doğurduğu askeri siyaset / militarizm noktasında ele almıştır. ${ }^{91}$ Aynı köşede 22 Temmuz' da "Çin hâdiselerinin iç yüzü" başlığı ile ikinci kez Japon-Çin meselesi analiz edilmiştir. Fakat bu analizde eski Endoşin Genel Valisi Aleksandr Varen'in Pari-Suar gazetesindeki Japon emperyalizmine yönelik açıklamalarına yer verilmiştir. Gerek Varen'in açıklamaları gerekse bu açıklamaları yayınlaması, Ulus'un çatışmanın kökeninde Japonya'yı haksız bulduğunu göstermektedir. ${ }^{92} 23$ Temmuz' da bu kez "Politika bahisleri”" isimli köşede konu, Burhan Belge tarafından değerlendirilmiştir. "Samuray'ın ruyası" başlıklı yazıda Japonya'nın Asya'ya

84 Ulus, 7 Temmuz 1937; Kurun 8 Temmuz 1937; Cumhuriyet, 7 Temmuz 1937; Akşam 9 Temmuz 1937.

85 Ulus, 9 Temmuz 1937; Kurun 9 Temmuz 1937; Cumhuriyet, 9 Temmuz 1937; Akşam 9 Temmuz 1937.

86 Ulus, 10 Temmuz 1937; Cumhuriyet, 10 Temmuz 1937; Kurun, 10 Temmuz 1937.

87 Ulus, 10 Temmuz 1937; Ulus, 11 Temmuz 1937; Ulus, 17 Temmuz 1937.

88 Ulus, 13 Temmuz 1937.

89 Ulus, 14 Temmuz 1937; Ulus, 15 Temmuz 1937; Ulus, 16 Temmuz 1937; Kurun 15-18 Temmuz 1937; Akşam 13 Temmuz 1937.

90 Ulus, 17 Temmuz 1937.

91 Ulus, 20 Temmuz 1937.

92 Ulus, 22 Temmuz 1937. 
doğru ilerlemesi bir rüya olarak ifade edilmiştir. Belge'nin destansı bir anlatımla hikayeleştirdiği süreçte, Çin'in Japonya'ya karşı mücadele gücünü arttırdığ ifade edilmiştir. ${ }^{93} 26$ Temmuz'da gerçekleşen Japonya'nın Pekin'i işgali ise birinci sayfadan duyurulmuştur. ${ }^{94}$ Ağustos ayından itibaren Uzakdoğu'daki gelişmelerin hızlanması üzerine, Japon-Çin meselesi ile ilgili haber ve değerlendirmelerin de arttı̆̆ 1 görülmüştür. ${ }^{95}$ Keza Cumhuriyet ve Tan gazetelerinde de benzer türde yazilara yer verilmiştir. ${ }^{96}$ Gelişmelerin yoğunlaşması sonucunda verilen haberlerin nicelik açısından artması karşısında Çin ve gerçekleşen işgal hakkında bilgi vermek üzere, 4 Ağustos'ta bir yazı kaleme alınmıştır. Bilgilendirme yazısı olmakla birlikte yazıda Elçilik raporlarında olduğu gibi Japonların yayılmacı oldukları ifadesine yer verilmiştir. ${ }^{97}$ Burhan Belge yaptığı değerlendirme ile İngiliz ekonomik ve politik çıkarlarının Hint ve Çin denizlerinde bulunduğunu ifade ederek İngiltere'nin Avrupa'daki meseleleri -İspanya gibi- bir an önce sona erdirip Çin'in yanında olacağını kaydetmiştir. ${ }^{98}$

Ulus'un diş politika ve dünya haberleri ile ilgili tasarrufu rastgele olmayıp belli bir anlayışı yansıtmaktadır. Bu doğrultuda başyazar Falih Rıfkı Atay, yazdığı "Gazetelerimiz ve dış politika" isimli başyazısında, Ulus dışındaki diğer gazetelerin de dış politika konusunda aynı görüşe sahip olduğunu ifade etmiştir.99 Atay, Japon-Çin çatışmalarının yoğun olarak sürdüğü bu dönemde kaleme aldığı yazıda, gazetelerin onda dokuzunun CHP'ye mensup olduğunu onuncunun ise dış politika konusunda aynı fikirlere sahip olduğunu ifade etmiştir. Atay, dış politika ve dünya gelişmeleri konusunda "anarşinin” önüne geçmek üzere tek bir otoritenin olmasını savunmuştur. Bu durumun sebebi ise Türkiye'yi uluslararası konuda zorda bırakmamak anlayışıdır. ${ }^{100}$ Türkiye'nin dünyadaki her gelişme ile ilgili haberleri dikkatli seçtiği dönemde Ahmet Şükrü Esmer'in kaleme aldığ "Japonyanın hedefi" isimli köşe yazısında Uzakdoğu gelişmelerini, resmi bir anlayış çerçevesinde değerlendirmiştir. Esmer, Japonya'nın hedefinin Çin'in Japonya'ya karşı "uysallaşması ve itaatkar" olması şeklinde olduğunu ifade etmiş-

93 Ulus, 23 Temmuz 1937.

94 Ulus, 27 Temmuz 1937.

95 Ulus, 2-31 Ağustos 1937; Kurun 1-31 Ağustos 1937;Ulus 1-30 Eylül 1937; Kurun 1-30 Eylül 1937.

96 Tan, 20 Ağustos 1937; Cumhuriyet, 3 Eylül 1937.

97 Ulus, 4 Ağustos 1937.

98 Ulus, 6 Ağustos 1937.

99 Bknz., Son Telgraf 13-14 Eylül 1937; Cumhuriyet, 11-14-15 Eylül 1937; Tan, 10-14 Eylül 1937.

100 Ulus, 9 Eylül 1937. 
tir. Japonya'nın Asya'da "Monroe kaidesi" siyaseti takip ederek Batı Avrupa ve ABD çıkarlarını tasfiyeye çalıştığını ifade eden Esmer, Japonya'nın büyük devletlerin arasındaki anlaşmazlıktan yararlandığını da kaydetmiştir. ${ }^{101}$ Gerek basın gerekse elçilik raporları, II. Dünya Savaşı öncesinde ortak bir anlayış içerisinde Türkiye'nin Japon-Çin meselesinde görüş birliği sağlamışlardır.

Siyasilerin açıklamaları da bu doğrultuda oldukça önemli olmuştur. Başbakan İsmet İnönü, verdiği bir beyanatta dünyada meydana gelen gelişmeleri, “Umumi buhran havası" olarak değerlendirmiş ve Türkiye'nin takip ettiği dış politikayı ise "her türlü vesaitle umumî sulha hizmet etmek" ve "milletler arasındaki uzlaşma" olarak belirtmiştir. ${ }^{102}$ Tehlikeden bahseden İsmet İnönü, 19 Eylül'de ise "Akdenizde ve Avrupada bir harb patlamasını" büyük bir facia olarak nitelendirmiştir. ${ }^{103}$ Dışişleri Bakanı Tevfik Rüştü Aras ise ABD’ye verdiği bir cevapta dış politika konusunda Türkiye ile ABD arasında uyum olduğunu ifade etmiştir. ${ }^{104}$ Mustafa Kemal Atatürk'ün Meclis'in açılışında yaptı̆̆ 1 dış politika değerlendirmesinde ise Türkiye'nin sulhe ve Milletler Cemiyeti'ne bağlı olduğu ifade edilirken Türkiye'nin Akdeniz' deki gelişmeleri yakından takip ettiği vurgulanmıştır. ${ }^{105}$ Dünya hızla II. Dünya Savaşı'na doğru ilerlerken, Türkiye, yaşanan gelişmeler sebebiyle, Uzakdoğu'dan ziyade yakın doğu ve batısındaki gelişmeleri öncelikli mesele olarak değerlendirmiştir. Bu minvalde 1938 yılının TBMM açılış konuşmasında ise -nutuk Celal Bayar tarafından okunmuştur- dış politikada Hatay, Balkan gelişmeleri ve Akdeniz meselesi önde tutulurken Uzakdoğu'daki gelişmeler tali bir mesele olarak kalmıştır. ${ }^{106}$

\section{Dünya Savaşı Öncesi Türkiye-Çin ve Türkiye-Japonya İlişkileri}

Türkiye'nin Çin ve Japonya ile ilişkilerine baktığımızda, Asya-Pasifik bölgesinde muhtemel bir savaş olacağını düşünen Türkiye, Japon-Çin meselesini dâhil olduğu Kellogg Paktı ve Milletler Cemiyeti sorumluluğu içerisinde görürken, uluslararası hukukun dışında her iki devletle de ikili ilişkilerini sürdürmüştür. Türkiye, Çin'le 1934 yılında Dostluk Antlaşması imzalamak üzere harekete geçmiştir. ${ }^{107}$ Fakat Türkiye, 1934 'ten çok daha önce, 1926 yılında iki ülke arasındaki

101 Ulus, 15 Eylül 1937.

102 Ulus, 19 Ağustos 1937.

103 Ulus, 19 Eylül 1937; Tan, 19 Eylül 1937; Cumhuriyet, 19 Eylül 1937.

104 Ulus, 2 Eylül 1937; Akşam 2 Eylül 1937.

105 TBMM Zabit Ceridesi, Devre: V, Cilt: 20, Toplant1: 3, Birinci inikad, 01.11.1937, s. 8-9.

106 TBMM Zabit Ceridesi, Devre: V, Cilt: 27, Toplant1: 4, Birinci inikad, 01.11.1938, s. 3-7.

107 BCA, 30-18-1-2 / 43-17-1 (Kararlar Daire Başkanlığı, 03.04.1934) 
ilişkileri geliştirmek üzere faaliyet göstermiştir. ${ }^{108} 1927$ yılından itibaren Japonya üzerinden yürütülen diplomatik ilişkiler, Türkiye'nin 1929 y1lında Çin'de ilk Türk elçiliğinin açılmasıyla birlikte doğrudan yürütülmeye başlanmıştır. ${ }^{109}$ Japon-Çin meselesi başladıktan sonra ise mevcut yapının olumlu bir biçimde sürdürüldügü görülmüştür. ${ }^{110}$ Çin yetkilileri 1933 yllında iktisadi incelemelerde bulunmak üzere Türkiye'ye gelmek isterken ${ }^{111}$, askeri yetkililerse 1934 y1lında Türkiye'de inceleme yapmışlardır. ${ }^{112}$ Olumlu bir havada sürdürülen gelişmeler neticesinde, 4 Nisan 1934 tarihinde Ankara'da, Türkiye ile Çin arasında Dostluk Antlaşması imzalanmıştır. ${ }^{13}$ Keza Çinli öğrencilerin Japon-Çin meselesinin tekrar hız kazandığı bir dönemde Türkiye'ye eğitim görmek üzere geldikleri ve ücretsiz eğitim almalarının sağlandığı görülmüştür. ${ }^{114}$

1939 yılında Türkiye, Çin'e yönelik yeni bir girişimde bulunarak Dışişleri Bakanlığı'nın teklifiyle Çin'e Orta Elçi atanmıştır. ${ }^{115}$ Türkiye, Japonya'yı Çin meselesinde yayılmacı görmekle birlikte, iki ülke arasındaki ilişkiler müspet bir seyir izlemiştir. 1925 yılında olumlu bir gelişme göstermeye başlayan ikili ilişkiler, Çin meselesinin çıkması sonrasında da devam etmiştir. ${ }^{116}$ Özellikle Türkiye'nin Japonya ile olan 1930'lu yıllardaki ilişkisi daha ziyade ekonomik temelli olmuştur. ${ }^{117}$ $\mathrm{Bu}$ çerçevede "Japon dış siyasetini çevirenlerin" iktisadi kolaylıklar göstererek iki devletin yakınlığını meydana getirmek arzusu içerisinde bulunduğu, Tokyo Elçiliği'nin senelik raporunda önemli bir tespit olarak kaydedilmiştir. ${ }^{118}$ Çin meselesi süresince Japonya'nın Türkiye'ye yönelik oldukça dikkat çekici bir dil kullandığı görülmüştür. Tokyo’ya giden Askeri Ataşeye Japon yetkililer, “şeref, ve milli izzeti nefis, itaat, fedakarlık, ve kahramanlık gibi manevi hasletler itibarile Japonlarla Türkler arasında hemen diğer Milletlerde olmayacak derecede bir

108 BCA, 30-18-1-1 / 18-25-4 (Kararlar Daire Başkanlığ1, 06.04.1926)

1091929 yılında açılan Elçilik, ekonomik sebeplerle 1931 yılında kapatılmıştır; Barış Adıbelli, Osmanlı'dan Günümüze Türk-Çin İlişkileri, İstanbul, IQ Kültür Sanat Yayınc1lık, 2016, s. 144-147.

110 BCA, 30-10-0-0 / 257-728-2 Dosya Ek: 434A (Muamelat Genel Müdürlüğü, 17.06.1929)

111 BCA, 30-10-0-0 / 200-366-17 Dosya Ek: 239 (Muamelat Genel Müdürlüğü, 29.06.1933)

112 BCA, 30-10-0-0 / 200-367-1 Dosya Ek: 239 (Muamelat Genel Müdürlüğü, 22.02.1934)

113 Resmi Gazete, 9 Haziran 1934, Say1: 2722, s. 3956.

114 BCA, 30-18-1-2 / 71-4-1 (Kararlar Daire Başkanlığ1, 14.01.1937); BCA, 30-18-1-2 / 84-87-4 (Kararlar Daire Başkanlığı, 28.09.1938)

115 BCA, 30-18-1-2 / 88-87-10 Dosya Ek: 107-109 (Kararlar Daire Başkanlığı, 04.09.1939)

116 BCA, 30-10-0-0 / 257-729-2 Dosya Ek: 434B (Muamelat Genel Müdürlüğü, 24.05.1925)

117 BCA, 30-18-1-2 / 52-11-14 (Kararlar Daire Başkanlığ 1 , 17.02.1935); BCA, 30-18-1-2 / 64-313 (Kararlar Daire Başkanlığı, 21.04.1936); BCA, 30-18-1-2 / 64-33-3-14 2 Dosya Ek: 2-5458 (Kararlar Daire Başkanlığ $1,29.04 .1936)$

118 BCA, 30-10-0-0 / 257-729-30 Dosya Ek: 434B (Muamelat Genel Müdürlügü, 00.00.1933) 
müşabehet olduğu" vurgulamıştır. Keza Lozan Antlaşması sırasında görev yapmış olan General Magata, İsmet İnönü’ye sunmak üzere bir şiir yazmıştır. ${ }^{119}$ Benzer bir biçimde Japonların Türkiye ile ilişkilere önem verdiğini gösteren bir gelişme ise Japon Prensi Takamatsu'nun eşi ve mahiyetle birlikte 1931 y1lında Türkiye'yi ziyaret etmesi olmuştur. ${ }^{120}$ Japonya'nın Türkiye'ye atfettiği önem resmi diplomatik temsiller sırasında da görülmüştür. Japonya Dışş̧leri Bakanı Mr. Koki Hirota, resmikabul sırasında Türkiye'nin Tokyo Maslahatgüzarını alışılmışın dışında olarak samimiyet göstererek "Dünyayı aydınlatan iki şey vardır. Biri ay diğeri güneş. Biri Türkiyenin diğeri Japonyanın timsalidir. Geleceğin politika dünyasını da aydınlatacak muhakkak bunlardır" dedikten sonra Türkiye ile yakın ilişkiler tesis etmek için mümkün olanı yapacağını ifade etmiştir. Hirota, hem Japonya'nın hem de Türkiye'nin SSCB ile dostane politikaları olduğunu ve bunun bir bağ olduğunu söylemiş̧ir. Maslahatgüzarın ifadesiyle Türkiye'nin Japonya'dan temel beklentisi ise ekonomiktir. ${ }^{121}$ İki ülke arasında bazı meselelerin problem olduğu da görülmüştür. Bu doğrultuda Şam' da sürgünde yaşayan Şehzade Abdülkerim Efendi'nin 1933 yılında Tokyo'yu, davet üzerine ziyaret etmesi ve bir yıl kadar burada kalması Türkiye'yi rahatsız eden bir gelişme olmuş ve gayrı resmi bir şekilde Türk Elçiliği Japon yetkilileri sözlü olarak protesto etmiştir. Yaşanan Şehzade vakas1 dışında ikili ilişkilerin sorunsuz olduğunu gösteren tarzda 1934 yılında TürkiyeJaponya Ticaret Antlaşması imzalanmıştır. ${ }^{122}$

Türkiye ile Japonya arasında gerçekleşen ve Türkiye'nin Japonya'ya II. Dünya Savaşı sırasında savaş ilan etmesine kadar iki ülke arasındaki ekonomik ilişkiler sürdürülmüş̧ür. ${ }^{123}$ Türkiye'nin Japonya' dan temel beklentisi iktisadi konular olmuştur. Savaş sırasında ise Japonya'nın Irak'la siyasi münasebetinin kesilmesi sebebiyle Japonlar, Irak’taki Japon menfaatlerinin korunması için diplomatik kanalları kullanarak Türkiye nezdinde devreye girmiştir. Japonya'nın Irak’taki menfaatlerinin korunmasında bir mahzur görülmemesi üzerine, Japonya'nın teklifi uygun bulunarak kabul edilmiştir. ${ }^{124}$

119 "Leman kıyılarına akseden ziya / Ankara ufuklarında parlıyan Hilalin ziyasıdır / Yeni Türkiye'nin kurtulması için titreyen kalp / yüksek muzafferiyetleri idrak eden (İsmet)indir.”; BCA, 30-10-0-0 / 257-729-20 Dosya Ek: 434B (Muamelat Genel Müdürlügü̈, 08.10.1932)

120 Mustafa Özyürek, “Cumhuriyet Dönemi Türkiye-Japonya İlişkileri Çerçevesinde Japon Prensi Takamatsu'nun Türkiye Ziyareti”, Atatürk Dergisi, cilt 5, sayı 2, 2016, s. 26.

121 BCA, 30-10-0-0 / 257-729-27 Dosya Ek: 434B (Muamelat Genel Müdürlüğü, 12.10.1933)

122 Selçuk Esenbel, “Türk-Japon İlişkilerinin Tarihi”, Türkler Ansiklopedisi, cilt 13, Ankara, 2002, s. $158-159$.

123 BCA, 30-10-0-0 / 235-590-18 Dosya Ek: 422 (Muamelat Genel Müdürlüğü, 25.05.1945)

124 BCA, 30-10-0-0 / 222-496-3 Dosya Ek: 400-3 (Muamelat Genel Müdürlüğü, 10.12.1941) 
Türkiye Uzakdoğu'da yaşanan gelişmeleri takip etmeyi, II. Dünya Savaş1 başladıktan sonra da sürdürmüştür. Bu doğrultuda Tokyo Elçiliği, Almanya-İtalya-Japonya arasında gerçekleşen üçlü Muahedeyi ve Japonya'daki yansımalarını ittifak-hedef noktasında ele alarak değerlendirmiştir. Bir çıkarımda bulunan Tokyo Elçiliği, SSCB'nin Muahedeyle birlikte, doğu ve batıdan bir çember içerisine alındığııı vurgulamıştır. ${ }^{125}$

\section{Sonuç}

II. Dünya Savaşı'nın çıkmasına neden olan en önemli gelişme, I. Dünya Savaşı sonrasında yapılan barış antlaşmalarının ortaya çıkardığı memnuniyetsizlik olmuştur. Avrupa' da özellikle Almanya'nın ortaya koyduğu memnuniyetsizlik, II. Dünya Savaşı'nın ana nedenlerindendir. Avrupa'daki gelişmelerin aksine Asya'da Japonya'nın ortaya çıkardığı durum ise I. Dünya Savaşı'nın sonuçlarından daha ziyade Japonya'nın 1905 yılından itibaren açığa vurduğu yayılmacılık anlayışının sonucu olmuştur. Japonya'nın Mançurya ve Çin'e yönelik genişleme arzusu, II. Dünya Savaşı öncesinde savaşın Uzakdoğu'ya çok daha erken gelmesine neden olmuştur. Henüz 1920'li yılların sonunda Çin-SSCB meselesi olarak Türkiye'nin ve de dünyanın gündemine giren Uzakdoğu meselesi, 1931 yılında Japonya'nın Mançurya'yı işgal etmesiyle birlikte Japon-Çin meselesi halini almış ve 1945 y1lında Japonya'nın II. Dünya Savaşı'ndan çekilmesine kadar da sürmüştür.

Avrupa açısından nispeten daha az önemli bir konu kabul edilmekle birlikte Japonya'nın yayılmacı emelleri, I. Dünya Savaşı sonrası kurulan düzene ve Milletler Cemiyeti'ne hasar vererek dünya siyasetinin sıkletini değiştirmiştir. Japonya'nın özellikle 1922'de gerçekleşen Washington Deniz Silahlanması Konferansı sonrası imzalanan antlaşmaları yok sayarak Asya-Pasifik bölgesinde tehdit unsuru olarak belirmesi, Avrupa merkezli Uzakdoğu anlayışının yerini SSCB, ABD ve Japonya arasında meydana gelen bir çekişme alanına bırakmasına yol açmıștır. Türkiye, Çin-SSCB meselesi dışarda tutulursa Japonya-Çin meselesinin çıktığ ilk andan itibaren konuyu uluslararası hukuk temelinde ve Avrupa ekseninde değerlendirmiştir. Uzakdoğu'da takip edilen Avrupa merkezli dış politika, Japonya'nın Milletler Cemiyeti'nden çekilmesi sonrasında, Avrupa kuvvetleri yerine ABD'nin Uzakdoğu'da etkinleşmeye başlamasıyla birlikte, Türkiye'nin süreci değerlendirmesi de nispeten yavaşlamıştır. Bu durumun meydana gelmesinde aynı zamanda İtalya'nın Akdeniz'de ve Balkanlarda meydana getirdiği güvenlik endişesi temel bir gerekçe olmuştur. Türkiye, Japon-Çin meselesinin nispeten Avrupa -İngiltere- merkezli dünya politikası gündeminde önemini kaybetmesiyle birlikte, Japonya yerine İtalya'nın meydana getirdiği güvenlik endişeleri doğrul- 
tusunda, Balkan Antantı, Sadabad Paktı gibi birinci derecede öncelikli güvenlik eksenli dış politika konularına yönelmiştir.

Türkiye'nin Uzakdoğu' da yaşanan gelişmeleri, diplomatik temsilcileri vas1tasıyla oldukça yakın bir şekilde takip ettiği görülmüştür. Türkiye, Çin-SSCB arasında meydana gelen ilk gerginlik sürecini, Türk dış politikası açısından SSCB nazarıyla ele alırken, çatışmada Japonya'nın ortaya çıkmasıyla birlikte, SSCB faktörünün nispeten azaldığ 1 ve sürecin daha farklı unsurlar açısından değerlendirildiği görülmüsstür. Türk dış politikası, 1929 yılından itibaren dolaylı olarak kendisini ilgilendiren Uzakdoğu meselesini ciddi bir biçimde takip ederek, sürecin dünya siyasetinde meydana getireceği etkiler doğrultusunda analizler yapmıştır. Çin-SSCB meselesinde SSCB’nin haklı olduğu kanısına varan Türkiye, Japon-Çin meselesinde ise Çin'in haklı olduğunu vurgulamıştır. Japonya'nın Mançurya'yı işgali ile başlayan süreci tarihsel perspektif doğrultusunda tahlil eden dış politika raporları, Japon yayılmacılığının tarihini XIX. yüzyıla kadar götürürken, daha yakın tarihli konjonktürel gelişmeleri de sürece eklemlemeyi ihmal etmemiştir. Özellikle sürekli artan Japon nüfusunun ve buna karşı yetersiz kalan Japonya topraklarının Japonya'nın emperyal amaçları için önemli bir neden olduğu, gerçekçi bir değerlendirme ile ortaya konmuştur. Keza süreç aynı zamanda Çin ve Japon iç politikaları açısından da yakinen takip edilmiştir. Çin'de meydana gelen ve çatışma halinde süren Milliyetçi-Komünist mücadelesinin Japonya ile sürdürülen savaşta ne tür bir role sahip olduğu önemli bir gerekçe olarak tespit edilmiştir. Aynı şekilde Japonya' daki mevcut politik yapıyı birkaç merhale olarak analiz eden dış politika raporları, Japonya'da artan militarist görüşün kamuoyunu yanına alarak Mançurya, Jehol, İç Moğolistan konularında Japonya'nın yayılmac1 emellerini beslediği gibi bir takım gerçekçi tespitlerde bulunmuştur.

Türkiye'nin Uzakdoğu diplomatik elçileri tarafından gönderilen dış politika raporları ve belgeleri, üslubu ve muhtevası itibariyle incelendiğinde Türkiye'nin Uzakdoğu'daki gelişmelere oldukça vakıf olduğu görülmüştür. Raporlarda süreç, tarihsel olayların yol açtığı gelişmeler ve konjonktürel gelişmeler 1şığında ele alınarak tahlil edilmiştir. Türkiye, dolaylı bir dahli olduğu Uzakdoğu meselesine, dünya barışı açısından yaklaşmış ve aktif bir tavır takınmıştır. Türkiye, dış politika açısından doğrudan bir çıkar alanı ihtiva etmeyen Japon-Çin meselesini, üyesi olduğu Milletler Cemiyeti ve imzacısı olduğu Kellogg Paktı çerçevesinde ele almıştır. Türkiye, dâhil olduğu süreç içerisinde çözüme yönelik Milletler Cemiyeti içerisinde oluşturulan "On Dokuzlar Komisyonu" gibi komitelerde aktif bir politika ortaya koyarken, haricen de gerek Çin gerekse Japon yetkili mercilerine telgraf göndererek her iki ülkenin de meseleyi barışçıl bir biçimde ele alması çağrısında bulunmuştur. Türkiye, Mançurya'yı işgali konusunda Japonya’yı 
haksız bulmakla birlikte, sürecin Türk dış politikasının önem verdiği uluslararası barış ve hukuk kuralları içerisinde nihayet bulması yönünde çaba göstermiştir.

Türkiye'nin Uzakdoğu'da takip ettiği politika iki dönem şeklinde ele alınabilir. İlk dönemde Türkiye, barışçıl kaideler etrafında Kellogg Paktı ve Milletler Cemiyeti ahkâmı etrafında uluslararası hukuka uygun bir dış politika anlayışı izlemiştir. Fakat Japonya'nın bağımsız Mançuko Devleti'ni kurması, tanıması, Milletler Cemiyeti'nden ayrılması ve Çin'in bazı eyaletlerini işgal etmesi karşısında Türkiye, Çin'in toprak bütünlüğünü savunmak şeklinde bir politika geliştirmiştir. Türkiye, Çin'in toprak bütünlüğünü savunduğu bu dönemde, Balkanlarda ve Akdeniz'de İtalya'nın ortaya koyduğu yayılmacı arzular, Türkiye'nin Uzakdoğu'daki gelişmelere öncelik tanımasına engel teşkil etmiştir. Bu süre içerisinde Japon-Çin çatışmalarının durması da yine bu durumu besleyen başka bir gerekçe olmuştur. Türkiye, sürece daha az dâhil olurken, gelişmeleri temsilcileri vasitasıyla takip etmeyi sürdürmüştür.

Türkiye, sürecin uluslararası hukukun dışına kayması sonrasında her iki devletle olan ilişkilerini ayrı bir bahis konusu olarak ele almıştır. Türkiye, Japonya'yı dünya barışını tehdit eden bir unsur addetmekle birlikte, gerek Çin'le gerekse Japonya'yla ikili ilişkilerini sürdürmüştür. Zira Türkiye, Japon-Çin meselesini dâhil olduğu Kellogg Paktı ve Milletler Cemiyeti sorumluluğu içerisinde görürken, uluslararası hukukun dişında her iki devletle de diplomatik teamüller gereği "bîtaraf" olarak ikili ilişkilerini devam ettirmiştir. Türkiye'nin “bîtaraf” olarak sürdürdüğü Çin ve Japonya ilişkilerine baktığımızda, Japonya'nın dünyadan kendisini izole ederek Çin'in içlerine doğru yayılmasını sürdürdüğü II. Dünya Savaşı öncesinde Türkiye, yaşadığı güvenlik endişelerine rağmen, ilişkileri rutin seviyede muhafaza etmiştir. Bu doğrultuda Japonya ile ekonomik gelişmelere önem veren Türkiye, 1945 yılına kadar Türk-Japon ilişkilerini ekonomik, askeri temelde sürdürmüştür. Keza Çin'le olan ilişkilerin de ekonomik temelli olmamakla birlikte sürdürüldüğü görülmüştür. Çin'den bu dönemde Türkiye'ye eğitim almak üzere öğrencilerin geldiği, askeri ve ekonomik heyetlerin Türkiye'yi ziyaret ettiği görülmüsstür.

Türkiye, dış politikası açısından Uzakdoğu'daki gelişmeleri 1929-1939 yılları arasında realist bir bakışla değerlendirmiştir. Barış eksenli Türk dış politikasının söylemi Çin-Japon meselesini kapsarken, Türkiye dâhil olduğu Milletler Cemiyeti ve Kellogg Paktı ekseninde uzunca bir süre aktif politika takip etmiştir. Japonya'nın Milletler Cemiyeti'nden ayrılması ve 1935 sonrası çatışmanın yavaşlaması, Türkiye'nin Akdeniz, Balkanlar ve Doğu sınırlarına öncelik vermesini gerektirmiştir. Türkiye, Japon-Çin meselesini uluslararası bir sorun olarak görüp bu eksende çözüme kavuşmasını isterken aynı zamanda her iki devletle olan ikili ilişkilerini sürdürmüştür. 


\section{Kaynakça}

\section{Arşiv Kaynakları}

Türkiye Cumhuriyeti Cumhurbaşkanlığı Devlet Arşivleri Başkanlığı, Cumhuriyet Arşivi (BCA)

BCA, 30-10-0-0 / 257-729-2 Dosya Ek: 434B (Muamelat Genel Müdürlüğü, 24.05.1925)

BCA, 30-18-1-1 / 18-25-4 (Kararlar Daire Başkanlığı, 06.04.1926)

BCA, 30-10-0-0 / 257-728-2 Dosya Ek: 434A (Muamelat Genel Müdürlüğü, 17.06.1929)

BCA, 30-10-0-0 / 257-729-11 Dosya Ek: 434B (Muamelat Genel Müdürlüğ̈̈)

BCA, 30-10-0-0 / 257-729-12 Dosya Ek: 434B (Muamelat Genel Müdürlüğ̈̈, 26.12.1929)

BCA, 30-10-0-0 / 257-728-4 Dosya Ek: 434A (Muamelat Genel Müdürlügüü, 20.10.1931)

BCA, 30-10-0-0 / 257-728-4 Dosya Ek: 434A (Muamelat Genel Müdürlüğü, 20.10.1931)

BCA, 30-10-0-0 / 257-728-5 Dosya Ek: 434A (Muamelat Genel Müdürlüğü, 21.10.1931)

BCA, 30-10-0-0 / 257-728-6 Dosya Ek: 434A (Muamelat Genel Müdürlüğü, 28.10.1931)

BCA, 30-10-0-0 / 248-676-13 Dosya Ek: 431 (Muamelat Genel Müdürlüğü, 03.11.1931)

BCA, 30-10-0-0 / 257-728-7 Dosya Ek: 434A (Muamelat Genel Müdürlüğü, 30.12.1931)

BCA, 30-10-0-0 / 257-729-20 Dosya Ek: 434B (Muamelat Genel Müdürlügü, 08.10.1932)

BCA, 30-10-0-0 / 257-729-21 Dosya Ek: 434B (Muamelat Genel Müdürlüğü, 12.10.1932)

BCA, 30-10-0-0 / 220-484-2 Dosya Ek: 400-3 (Muamelat Genel Müdürlüğü, $05.11 .1932)$

BCA, 30-10-0-0 / 257-728-9 Dosya Ek: 434A (Muamelat Genel Müdürlüğü, 28.11.1932) 
BCA, 30-10-0-0 / 257-726-4 Dosya Ek: 434 (Muamelat Genel Müdürlügüü, 03.12.1932)

BCA, 30-18-1-2 / 32-74-14 Dosya Ek: 401-11 (Kararlar Daire Başkanlığı, 13.12.1932)

BCA, 30-10-0-0 / 245-657-26 Dosya Ek: 429 (Muamelat Genel Müdürlüğü, 21.12.1932)

BCA, 30-10-0-0 / 257-729-20 Dosya Ek: 434B (Muamelat Genel Müdürlügü, 08.10.1932)

BCA, 30-10-0-0 / 257-728-4 Dosya Ek: 434A (Muamelat Genel Müdürlüğü, 20.10.1931)

BCA, 30-10-0-0 / 257-726-7 Dosya Ek: 434 (Muamelat Genel Müdürlügüü, 29.12.1932)

BCA, 30-10-0-0 / 220-485-3 Dosya Ek: 400-3 (Muamelat Genel Müdürlüğü, 12.01.1933)

BCA, 30-10-0-0 / 257-729-30 Dosya Ek: 434B (Muamelat Genel Müdürlüğü, 00.00.1933)

BCA, 30-10-0-0 / 220-486-10 Dosya Ek: 400-3 (Muamelat Genel Müdürlüğü, 14.03.1933)

BCA, 30-10-0-0 / 222-498-13 Dosya Ek: 401 (Muamelat Genel Müdürlüğü, 25.01.1933)

BCA, 30-10-0-0 / 257-726-11 Dosya Ek: 434 (Muamelat Genel Müdürlüğü, 15.02.1933)

BCA, 30-10-0-0 / 257-726-15 Dosya Ek: 434 (Muamelat Genel Müdürlüğü, 25.02.1933)

BCA, 30-10-0-0 / 267-802-8 Dosya Ek: 440 (Muamelat Genel Müdürlüğü, 02.03.1933)

BCA, 30-10-0-0 / 257-727-2 Dosya Ek: 434 (Muamelat Genel Müdürlüğü, 09.03.1933)

BCA, 30-10-0-0 / 220-486-13 Dosya Ek: 400-3 (Muamelat Genel Müdürlü$\breve{g u ̈}, 25.03 .1933$ )

BCA, 30-10-0-0 / 257-727-5 Dosya Ek: 434 (Muamelat Genel Müdürlüğü, 10.04.1933)

BCA, 30-10-0-0 / 257-727-11 Dosya Ek: 434 (Muamelat Genel Müdürlüğü, 20.05.1933) 
BCA, 30-10-0-0 / 257-727-8 Dosya Ek: 434 (Muamelat Genel Müdürlügüü, 14.05.1933)

BCA, 30-10-0-0 / 257 - 727 - 9 Dosya Ek: 434 (Muamelat Genel Müdürlüğü, 14.05.1933)

BCA, 30-10-0-0 / 257-727-13 Dosya Ek: 434 (Muamelat Genel Müdürlüğü, 03.06.1933)

BCA, 30-10-0-0 / 257-728-10 Dosya Ek: 434A (Muamelat Genel Müdürlügü̈, 20.05.1933)

BCA, 30-10-0-0 / 221-488-7 Dosya Ek: 400-3 (Muamelat Genel Müdürlüğü, 21.06.1933)

BCA, 30-10-0-0 / 200-366-17 Dosya Ek: 239 (Muamelat Genel Müdürlüğü, 29.06.1933)

BCA, 30-10-0-0 / 257-729-27 Dosya Ek: 434B (Muamelat Genel Müdürlügü, 12.10.1933)

BCA, 30-10-0-0 / 220-367-1 Dosya Ek: 239 (Muamelat Genel Müdürlüğü, 22.02.1934)

BCA, 30-10-0-0 / 221-490-7 Dosya Ek: 400-3 (Muamelat Genel Müdürlüğü, 14.05.1934)

BCA, 490-1-0-0 / 609-111-2 Dosya Ek: 3. Büro (Muamelat Genel Müdürlüğü, 14.05.1934)

BCA, 30-10-0-0 / 200-367-1 Dosya Ek: 239 (Muamelat Genel Müdürlüğü, $22.02 .1934)$

BCA, 30-18-1-2 / 43-17-1 (Kararlar Daire Başkanlığ1, 03.04.1934)

BCA, 30-10-0-0 / 221-490-17 Dosya Ek: 400-3 (Muamelat Genel Müdürlügü̈, 15.08.1934)

BCA, 30-18-1-2 / 52-11-14 (Kararlar Daire Başkanlığı, 17.02.1935)

BCA, 30-10-0-0 / 257-727-15 Dosya Ek: 434 (Muamelat Genel Müdürlüğü, 09.01.1936)

BCA, 30-18-1-2 / 64-31-3 (Kararlar Daire Başkanlığı, 21.04.1936)

BCA, 30-18-1-2 / 64-33-3-14 2 Dosya Ek: 2-5458 (Kararlar Daire Başkanlığ $1,29.04 .1936)$

BCA, 30-10-0-0 / 221-492-43 Dosya Ek: 400-3 (Muamelat Genel Müdürlügü, 02.12.1936) 
BCA, 30-18-1-2 / 71-4-1 (Kararlar Daire Başkanlığı, 14.01.1937)

BCA, 30-18-1-2 / 84-87-4 (Kararlar Daire Başkanlığı, 28.09.1938)

BCA, 30-18-1-2 / 88-87-10 Dosya Ek: 107-109 (Kararlar Daire Başkanlığı, 04.09.1939)

BCA, 30-1-0-0 / 60-367-13 Dosya Ek: E4 (Başbakanlık Özel Kalem Müdürlüğü, 02.10.1940)

BCA, 30-10-0-0 / 222-496-3 Dosya Ek: 400-3 (Muamelat Genel Müdürlügüü, 10.12.1941)

BCA, 30-10-0-0 / 235-590-18 Dosya Ek: 422 (Muamelat Genel Müdürlüğü, 25.05.1945)

\section{Süreli Yayınlar}

Akşam

Cumhuriyet

Kurun

Resmi Gazete

Son Telgraf

Tan

TBMM Zabit Ceridesi

Ulus

\section{Kaynak Eser ve İncelemeler}

Adıbelli, Barış, Osmanlı'dan Günümüze Türk-Çin İlişkileri, İstanbul, IQ Kültür Sanat Yayınc1lik, 2016.

Anzerlioğlu, Yonca, “Tokyo Türk Maslahatgüzarının Değerlendirmeleriyle Mançukuo Devleti (1931-1933)" Ankara Üniversitesi Türk inkılâp Tarihi Enstitüsü Atatürk Yolu Dergisi, say1 41, May1s 2008.

Armaoğlu, Fahir, 20. Yüzyıl Siyasî Tarihi 1914-1995, Alkım Yayınevi, t.y.

Belge, Murat, Militarist Modernleşme Almanya, Japonya ve Türkiye, 2. bs., İstanbul, İletişim Yayınları, 2012.

Benedict, Ruth, Krizantem ve Kılıç Japon Kültürü̈ Üzerine Bir Inceleme, çev. Türkân Turgut, İstanbul, İş Bankası Kültür Yayınları, 2011.

Çağdaş Türk Diplomasisi: 200 Yıllık Süreç, Ankara, Türk Tarih Kurumu Basımevi, 1999. 
D1şişleri Bakanlığı Araştırma ve Siyaset Planlama Genel Müdürlügü̈, Türkiye Dış Politikasında 50 Yıl Montreux ve Savaş Öncesi Yılları (1935-1939).

Eberhard, Wolfram, Çin Tarihi, Ankara, Türk Tarih Kurumu Basımevi, 1995.

Esenbel, Selçuk, “Türk-Japon İlişkilerinin Tarihi”, Türkler Ansiklopedisi, cilt 13, Ankara, 2002.

Hart, Liddell, II. Dünya Savaşı Tarihi Cilt I, çev. Kerim Bağrıçık, Yapı Kredi Yayınlar1, t.y.

Hobsbawm, Eric, Kısa 20. Yüzyıl 1914-1991 Aşırılıklar Çă̆ı, çev. Yavuz Alogan, İstanbul, Sarmal Yayınevi, 1996.

Hunter, Janet E., Modern Japonya’nın Doğuşu 1853 'ten Günümüze, çev. Müfit Günay, İmge Kitabevi, 2002.

İpşirli, Mehmet, “Osmanlı Devletinde 'Eman’ Sistemi”, Çağdaş Türk Diplomasisi: 200 Yıllık Süreç, Ankara, Türk Tarih Kurumu Basımevi, 1999.

Karaca, Erdem, "T.C. Hariciye Nezareti Siyasi Istihbarat Servisi Raporlarında Mançurya Meselesi (1932-1933)", Sosyal Bilimler Tarih ve Sanat (Bilimsel Araştırmalar Kitabı 2018), ed. Osman Köse, Ankara, 2018.

Koçak, Cemil, Türk-Alman Illişkileri (1923-1939) İki Dünya Savaşı Arasındaki Dönemde Siyasal, Kültürel, Askeri ve Ekonomik Illişkiler, 2. bs., Ankara, Türk Tarih Kurumu Yayınları, 2013.

Köni, Hasan, "Genel Dış Politika Işığında Cumhuriyet Dönemi Uzak-Doğu İlişkileri: 1933-36”, Ankara Üniversitesi Türk İnkılap Tarihi Enstitüsü Atatürk Yolu Dergisi, cilt 3, say1 11, 1993.

Kösebalaban, Hasan, "Japon Grand Stratejisi: Yirminci Yüzyı1 Japon Dış Politikasında Süreklilik ve Değişim”, Divan, cilt 3, sayı 5, 1998.

Lacoste, Yves, Büyük Oyunu Anlamak Jeopolitik: Bugünün Uzun Tarihi, 2. bs., NTV Yayınlar1, 2008.

McNeill, William H., Dünya Tarihi, çev. Alâeddin Şenel, 6. bs., İmge Kitabevi Yayınları, 2002.

Mercan, M. Salih, "II. Dünya Savaşı Öncesinde Çin-Japon Münasebetlerinde Mançurya (1931)”, Yüzüncü Yıl Üniversitesi Sosyal Bilimler Enstitüsü Dergisi, say1 30, 2016.

Oran, Baskın “Lozan'ın Öncülü Bir Onur Anıtı: Müttefiklerin Sevr Barış Antlaşması Tasarısına Osmanlı Hariciyesinin Yanıtı”, Çă̆daş Türk Diplomasisi: 200 Yıllık Süreç, Ankara, Türk Tarih Kurumu Basımevi, 1999. 
Özyürek, Mustafa, "Cumhuriyet Dönemi Türkiye-Japonya İlişkileri Çerçevesinde Japon Prensi Takamatsu'nun Türkiye Ziyareti”, Atatürk Dergisi, cilt 5, say1 2, 2016.

Ponting, Clive, Yeni Bir Bakış Açısıyla Dünya Tarihi, çev. Eşref Bengi Özbilen, Alfa Yayınları, 2011.

Sertel, Sabiha, II. Dünya Savaşı Tarihi, İstanbul, Cumhuriyet Kitapları, 2009.

Sander, Oral, Siyasi Tarih 1918-1994, 5. bs., Ankara, İmge Kitabevi, 1996. ,Siyasi Tarih İlkçă̆lardan $1918^{\prime}$ e, 12. bs., Ankara, İmge Kitabevi, 2003.

Savaş, Ali İbrahim, Osmanlı Diplomasisi, İstanbul, 3F Yayınevi, 2007.

Sugihara, Kaoru, Japan, China, and the Growth of the Asian International Economy 1850-1949, ed. Kaoru Sugihara, vol I, Oxford University Press, 2005.

Turp, Muharrem, "Türkiye-Japonya Arasında Diplomatik İlişkilerin Yeniden Tesisi ve Siyasi İktisadi İlişkiler (1951-1960)", Atatürk Üniversitesi Türkiyat Araştırmaları Enstitüsü Dergisi, sayı 69, 2020.

Uçarol, Rifat, Siyasi Tarih (1789-1999), 5. bs., İstanbul, Filiz Kitabevi, 2000. 